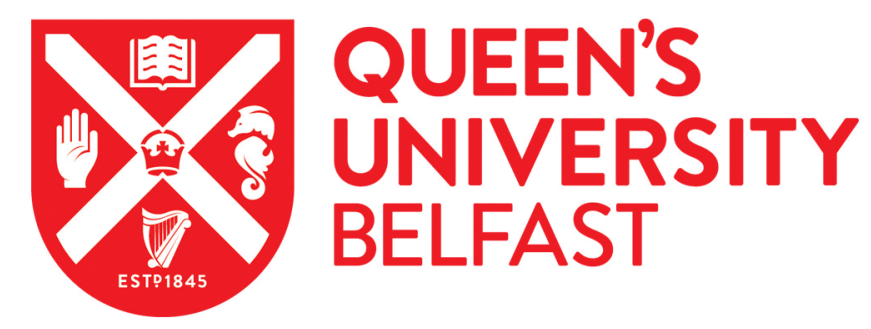

\title{
Self-assembling Ultrashort NSAID-Peptide Nanosponges: Multifunctional Antimicrobial and Anti-inflammatory Materials
}

\author{
McCloskey, A. P., Gilmore, S. M., Zhou, J., Draper, E. R., Porter, S., Gilmore, B., Xu, B., \& Laverty, G. (2016). \\ Self-assembling Ultrashort NSAID-Peptide Nanosponges: Multifunctional Antimicrobial and Anti-inflammatory \\ Materials. RSC Advances, 6(115), 114738-114749. https://doi.org/10.1039/C6RA20282A
}

Published in:

RSC Advances

Document Version:

Early version, also known as pre-print

Queen's University Belfast - Research Portal:

Link to publication record in Queen's University Belfast Research Portal

Publisher rights

Copyright 2016 The Authors

\section{General rights}

Copyright for the publications made accessible via the Queen's University Belfast Research Portal is retained by the author(s) and / or other copyright owners and it is a condition of accessing these publications that users recognise and abide by the legal requirements associated with these rights.

Take down policy

The Research Portal is Queen's institutional repository that provides access to Queen's research output. Every effort has been made to ensure that content in the Research Portal does not infringe any person's rights, or applicable UK laws. If you discover content in the Research Portal that you believe breaches copyright or violates any law, please contact openaccess@qub.ac.uk. 


\section{Self-assembling Ultrashort NSAID-Peptides: Multifunctional Antimicrobial and Anti- inflammatory Nanomaterials}

Alice P. McCloskey, Sophie M. Gilmore, Jie Zhou, Emily R. Draper, Simon Porter, Brendan F. Gilmore, Bing Xu, Garry Laverty*

A.P. McCloskey, S.M. Gilmore, S. Porter, Prof. B.F. Gilmore, Dr. G. Laverty.

Biofunctional nanomaterials group, School of Pharmacy, Queen's University, Belfast, BT9

7BL, N. Ireland.

E-mail: garry.laverty@qub.ac.uk

Fax: +44 (0)289024 7794

J. Zhou, Prof. B. Xu.

Department of Chemistry, Brandeis University, Waltham, Massachusetts, MA 02454, USA

E.R. Draper.

Department of Chemistry, University of Liverpool, Liverpool, L69 7ZD, UK.

\section{Abstract}

Peptide-based materials are receiving significant attention for use within biomedicine due to their high chemical and functional versatility enabling tailoring of their structure to replicate the properties of host tissue and the extracellular matrix. This paper studies the design, synthesis and characterization of NSAID-peptide conjugates. Attachment of NSAIDs to a diphenylalanine-dilysine (FFKK-OH) peptide sequence generates supramolecular hydrogel forming molecules with antimicrobial and anti-inflammatory properties. NSAID-peptides demonstrate broad-spectrum antimicrobial activity against both Gram-positive and Gramnegative bacteria implicated in a variety of antimicrobial resistant nosocomial infections including Staphylococcus aureus and Pseudomonas aeruginosa. Naproxen-peptides show particular promise, forming biocompatible nanofibrous viscoelastic hydrogels composed of $\beta$ sheet secondary structures at low concentrations $(0.4 \% \mathrm{w} / \mathrm{v})$. Conjugation of the peptide motif FFKK-OH to naproxen increases selectivity for COX-2 enzyme, implicated in chronic wound scar-tissue formation. Our findings suggest that ultrashort NSAID-peptides have potential use as multifunctional materials for a range of biomedical applications. This includes as topical agents for treatment of chronic wounds, where a profile of persistent inflammation, pain and 
the presence of infection has been proven to be detrimental to successful wound repair. This work may also serve as a template for the design of future medical device coatings with tailored antimicrobial and anti-inflammatory properties.

Keywords: Nanostructure, hydrogel, infection, inflammation, chronic wound

\section{Introduction}

Antimicrobial resistance is becoming an increasingly menacing threat to society and is currently attributed to at least 700,000 deaths worldwide annually. A U.K Government review in 2014 concluded that without significant investment in new therapies this total would increase to more than 10 million deaths by 2050, a figure greater than predicted for cancer [1]. Hospital-acquired infections, especially those related to implantation of medical devices and skin wounds, are major contributors to this threat demonstrating an increased prevalence of microorganisms that display resistance to standardly employed antimicrobial therapies. These are responsible for increased patient morbidity and mortality, and significant economic cost due to extended hospital stay/sick days. Infections are particularly problematic among those with increased susceptibility and compromised immunity, for example the elderly and those with under-lying disease.

Wound infections can be categorized into a variety of forms; most problematic being surgical site infections (SSIs), diabetic ulcers and major trauma, for example burns. SSIs are one of the most frequently reported hospital acquired infections accounting for $31 \%$ of nosocomial infections and are a reservoir for so-called hospital superbugs including Staphylococcus aureus and Pseudomonas aeruginosa [2]. SSIs are present in nearly 5\% of patients who undergo a surgical procedure and over a third of postoperative deaths are related to SSIs [3]. It 
is clear SSIs remain a significant burden to healthcare. Failure of antimicrobial therapy and/or unresolved healing can result in the development of a chronic wound.

Chronic infected wounds are particularly problematic with a profile of exaggerated inflammation and resistant infection severely limiting wound healing [4]. They are responsible for multiple treatment failures and commonly require a minimum of eight weeks to fully resolve, due to increased microbial resistance to standard drug regimens and impaired healing. Nonhealing wounds costs the US healthcare system \$3billion annually and affects over $2 \%$ of the population [5,6]. Acute and chronic wounds are resolved through similar biomolecular pathways, however chronic wounds commonly stall in the inflammatory phase partly due to the presence of pathogenic biofilm infection [7]. Implanted biomaterials are also associated with an exaggerated host immune response, termed the foreign body response. Sustained inflammation, present primarily within chronic wounds and biomaterial infections, has been proven to be detrimental to wound repair [8]. This has commonly been minimized and controlled using steroidal and non-steroidal anti-inflammatory drugs (NSAIDs), limiting the action of inflammatory mediators such as prostaglandins. Long-term systemic use of such drugs leads to undesirable side effects including adverse gastrointestinal, renal and cardiovascular risks. Debate still exists regarding the use of systemic NSAIDs to aid wound repair due to possible anti-proliferative effects demonstrated in animal studies and their possible contribution to increasing the severity of group A streptococcal infections [9][10]. Despite reservations with systemic NSAID use, localized sustained release systems are commonly employed and NSAID topical applications demonstrate benefit in the treatment of chronic wounds [11]. For example an ibuprofen foam formulation provides localized delivery, reduced pain, a moist environment and has been proven to be advantageous for the resolution of chronic venous leg ulcers [12]. 
There has been increased interest in the therapeutic potential of antimicrobial peptides. Displaying multiple modes of intracellular and extracellular action, antimicrobial peptides demonstrate a reduced propensity for developing antimicrobial resistance and are a significant prospect for solving the current shortage of antimicrobials in pharmaceutical development [13]. Several research groups have studied their incorporation into synthetic hydrogel matrices for the prevention of biomaterial and wound infections with promising results thus far $[14,15,16]$. Hydrogels possessing inherent antimicrobial properties represent a significant benefit by reducing microbial contamination within the matrix and at the wound/implantation site [17]. Self-assembling biomimetic hydrogels, including peptide-based strategies, have received attention as biofunctional materials and drug delivery platforms due to their similarity to the extracellular tissue matrix. Peptide-based materials possess: increased chemical functionality and versatility; improved biocompatibility; increased water capacity; moisture vapor transmission and gaseous exchange; biodegradability and tailored immunogenicity. Hydrogels provide improved healing at wound sites by enabling rapid absorption of wound exudate and protection of newly formed skin. Researchers have begun to employ a strategy whereby peptides are optimized to obtain multi-functionality, both pharmacological (antimicrobial, anti-biofilm, anti-inflammatory, analgesia) and physical (self-assembly, hydrogelation), within a single molecule. Most recently our group developed an ultrashort cationic peptide motif with selective activity against resistant pathogens implicated in medical device related infections [18]. Ultrashort peptides are of particular interest to the pharmaceutical industry as they are generally more cost-effective to synthesize relative to their larger peptide/protein counterparts and therefore more realistic molecules for clinical translation.

Self-assembling hydrogel systems based on drug molecules eliminates the necessity for a drug delivery vehicle, typically a synthetic polymer $[19,20]$ and may be tailored to respond to 
environmental and physiological stimuli, for example $\mathrm{pH}$ change or the presence of specific enzymes. Synthetic-based polymers demonstrate limited drug loading, are difficult to functionalize and acidic degradation products can induce an unwanted inflammatory response [21]. The presence of aromatic groups, such as those present within NSAIDs, facilitates assembly of NSAID-peptide conjugates where the NSAID moiety replaces more traditional aromatic groups found in self-assembling systems such as carboxybenzyl [22], 9fluorenylmethyloxycarbonyl (Fmoc) [23] and 2-naphthoyl (Nap) [24]. Work thus far has focused on NSAIDs clinically used as topical preparations for acute pain, for example ibuprofen and naproxen [25]. Recently a multifunctional approach has been successful in creating an anti-inflammatory and anti-HIV hydrogel using naproxen conjugated to reverse transcriptase inhibitors via a peptide linker [26]. The idea of a multifunctional antimicrobial and anti-inflammatory platform is adopted from nature where herb extracts curcumin (Curuma longa), dayflower (Commelina diffusa) and bark (Spathodea campanulata) have demonstrated benefit in wound healing [27,28] Building on previously investigated NSAID conjugated peptides and antimicrobial peptides we have developed novel self-assembling NSAID-peptides utilizing racemic ( \pm )-ibuprofen (Ibu), indomethacin (Ind) and (S)-(+)naproxen (Npx) (Figure 1).

This report examines the synthesis and characterization of NSAID conjugated ultrashort cationic self-assembled peptide hydrogels as potential antimicrobial and anti-inflammatory biomaterials. Incorporation of an NSAID into the ultrashort carboxylic acid terminated motif (FFKK-OH) was hypothesized to confer improved hydrogel strength and cyclooxygenase (COX) inhibitory properties to the molecule. The development of a NSAID conjugated hydrogelator may also serve as a carrier for other therapeutic agents since the arrest of the inflammatory response is one of the most important factors in successful application of biomaterials [29]. 


\section{Materials and Methods}

Materials

Wang resin preloaded with Fmoc-Lys(Boc) (mesh size 100-200, 0.65 mmol/g substitution), (2-(1H-benzotriazol-1-yl)-1,1,3,3-tetramethyluronium hexafluorophosphate) (HBTU), diisopropyl ethylamine (DIEA), Fmoc and Boc protected amino acids were obtained from Novabiochem, Merck KGaA (Dramstadt, Germany). 37\% hydrochloric acid ( $\mathrm{HCl})$, sodium hydroxide anhydrous pellets ( $\geq 99 \%$ ), acetonitrile (HPLC grade, $\geq 99.93 \%),( \pm)$-ibuprofen ( $\geq 98 \%$ ), indomethacin ( $\geq 99 \%)$, (S)-(+)-naproxen ( $\geq 99 \%)$, deuterated dimethyl sulfoxide ( $\mathrm{d}_{6-}$ DMSO), deuterium oxide $\left(\mathrm{D}_{2} \mathrm{O}\right)$, deuterium chloride ( $\left.\mathrm{DCl}\right)$, sodium deuteroxide $(\mathrm{NaOD})$, trifluoracetic acid, triisopropylsilane, thioanisole and Whatman $\mathrm{pH}$ indicator paper ( $\mathrm{pH} 1-14)$ were purchased from Sigma-Aldrich (Dorset, U.K.). NCTC Clone 929 (ATCC CCL 1) murine fibroblast subcutaneous connective tissue cells, S. epidermidis (ATCC 25984), S. aureus (ATCC 6584), P. aeruginosa (PAO1) and E. coli (ATCC 11303) supplied by LGC Standards (London, U.K). AlamarBlue ${ }^{\circledR}$ was obtained from AbD Serotec (Oxford, U.K.). Sterile Nunc TM 96-well microtiter plates supplied by VWR International (Leicestershire, U.K.). Fresh defibrinated equine erythrocytes were purchased from Laboratory Supplies and Instruments Ltd (Antrim, U.K.). Cayman's COX fluorescent inhibitor screening assay kit was obtained from Cambridge Bioscience Ltd (Cambridge, U.K.).

Methods

Synthesis, Purification and Identification

NSAID-peptide hybrids (IbuFFKK, IndFFKK and NpxFFKK) were synthesized as per standard Fmoc-based solid-phase peptide methods using a nitrogen bubbler apparatus [18]. Wang resin preloaded with Fmoc-Lys(Boc) was utilized to produce carboxylic acid terminated peptides, upon cleavage with $95 \% \mathrm{v} / \mathrm{v}$ trifluoracetic acid, $2.5 \% \mathrm{v} / \mathrm{v}$ triisopropylsilane and $2.5 \% \mathrm{v} / \mathrm{v}$ thioanisole for 3 hours at room temperature. The peptide 
amine terminus was conjugated to the corresponding carboxylic acid of the NSAID before cleavage. Standard HBTU coupling was performed in dimethylformamide (DMF) with 4-fold molar excess of DIEA and 3-fold excess of Fmoc-protected amino acid or NSAID used for coupling for 3 hours at room temperature. Precipitation was achieved using cold diethyl ether $\left(-20^{\circ} \mathrm{C}\right)$. Crude product was dissolved in ethyl acetate and subjected to a series of washes with $1 \mathrm{mM} \mathrm{HCl}(3 \times 50 \mathrm{ml})$ and water $(3 \times 50 \mathrm{ml}$ and dried over anhydrous magnesium sulfate $\left(\mathrm{MgSO}_{4}\right)$. NSAID-peptide identities were confirmed using ${ }^{1} \mathrm{H}$ NMR analysis (Varian Unity Inova 400 spectrometer, Varian systems, Palo Alto, California, U.S.A.) in $\mathrm{d}_{6}$-DMSO and electrospray mass spectroscopy (Thermo Finnigan LCQ Deca ion trap, Thermo Fisher Scientific, Waltham, Massachusetts, U.S.A.). NSAID-peptide purity was determined by reverse-phase-HPLC (Agilent 1260 series, Agilent Technologies Ltd, Cork, Ireland), using a Gemini C18 column (250 mm x $4.6 \mathrm{~mm})$ with a flow rate of $1.5 \mathrm{~mL} / \mathrm{min}$ and gradient of 2$60 \%$ acetonitrile (30 minutes) in $0.05 \%$ TFA-water. All NSAID-peptides were found to have purity greater than $95 \%$.

\section{Self-Assembling pH-Triggered Gelation}

NSAID-peptide hydrogels prepared by a process of $\mathrm{pH}$-triggered induction [18]. The method of gelation followed the sequence of steps outlined for of $2 \% \mathrm{w} / \mathrm{v}$ NSAID-peptide formulations in Table 1. A stock solution was prepared by suspending each NSAID-peptide in deionized water. Complete dissolution was achieved at $\mathrm{pH} 9$ via titration with $1 \mathrm{M} \mathrm{NaOH}$ due to deprotonation of the terminal carboxylic acid moiety. Changes in $\mathrm{pH}$ were monitored using Whatman $\mathrm{pH}$ paper. Protonation of the terminal carboxylate ion, by titration with $0.5 \mathrm{M} \mathrm{HCl}$ to $\mathrm{pH} 7$, enabled formation of homogeneous hydrogels at concentrations above the minimum gelation concentration $(\% \mathrm{w} / \mathrm{v})$ for each molecule. Minimum gelation concentration $(\% \mathrm{w} / \mathrm{v})$ was defined as the lowest concentration of NSAID-peptide that formed a self-supporting hydrogel, observed via a gel inversion assay after 24 hours development [30]. Gels and 
solutions were differentiated based on flow characteristics with gels remaining suspended and solutions demonstrating flow.

Cryo-Scanning Electron and Transmission Electron Microscopy

NSAID-peptides were prepared via $\mathrm{pH}$ induction as described and analyzed for 3D

morphology using a Hitachi Analytical Benchtop SEM TM3030 (Hitachi High-Technologies

Europe, Berkshire, U.K.) with Deben Cool Stage (Deben, Suffolk, U.K.). Cryo-SEM samples

were freeze-dried by vacuum lyophilization at $2{ }^{\circ} \mathrm{C}$. Images were obtained at $-10{ }^{\circ} \mathrm{C}$, using an accelerating voltage of $15 \mathrm{kV}$ and a range of magnifications (15-30 000x) [31]. TEM was performed using a FEI Morgagni 268 transmission electron microscope (FEI electronics, Burlington, Massachusetts, U.S.A.). A negative staining technique was employed [31]. TEM samples were placed on 400 mesh copper grids, glow discharged and coated with a carbon film $(35 \mathrm{~nm})$, rinsed thrice with double distilled water, then stained trice with a $2 \% \mathrm{w} / \mathrm{v}$ solution of uranyl acetate. Excess stain was removed by blotting with filter paper. The grids were left to air dry prior to examination of the 3D architecture of the NSAID-peptide samples.

\section{Fourier Transform Infra-Red Spectroscopy}

FTIR spectra were obtained at a resolution of $2 \mathrm{~cm}^{-1}$ and over wavelengths $4000-400 \mathrm{~cm}^{-1}$ (128 scans) using a Jasco 4000 series FTIR spectrometer (Jasco Inc. Tokyo, Japan). Samples were prepared as described above but using deuterated solvents $\left(\mathrm{D}_{2} \mathrm{O}, \mathrm{DCl}, \mathrm{NaOD}\right)$. Hydrogels were sandwiched between two calcium fluoride discs $(0.05 \mathrm{~mm}$ spacer $)$. A $\mathrm{D}_{2} \mathrm{O}$, $\mathrm{DCl}, \mathrm{NaOD}$ mixture, prepared to the same concentrations as NSAID-peptide containing samples, was used as a background and subtracted from all spectra. 


\section{Oscillatory Rheology}

Dynamic rheological measurements were performed using an Anton Paar Physica MCR301 rheometer. A cup and vane measuring system was used to perform frequency sweeps. For frequency $2 \mathrm{~mL}$ of the gels were prepared in $7 \mathrm{~mL}$ Sterilin vials as described previously [30]. All experiments were performed at $25^{\circ} \mathrm{C}$ from $1-100 \mathrm{rad} \mathrm{s}^{-1}$ at a strain of $0.0003 \%$.

\section{Bacterial Susceptibility Assay}

The ability of NSAID-peptides to reduce bacterial viability were tested using a colony counting method previously outlined by Mateescu and Jiang [32,33]. S. epidermidis (ATCC 25984), S. aureus (ATCC 6584), P. aeruginosa (PAO1) and E. coli (ATCC 11303) were subcultured for 24 hours at $37^{\circ} \mathrm{C}$ in Müller Hinton broth (MHB), optically adjusted to an optical density reading of 0.3 at $550 \mathrm{~nm}\left(1 \times 10^{8}\right.$ colony forming units per milliter $\left.(\mathrm{CFU} / \mathrm{mL})\right)$ in phosphate buffered saline (PBS) and further diluted in MHB (equivalent to $2 \times 10^{6}$ $\mathrm{CFU} / \mathrm{mL}$ ) prior to plating $100 \mu \mathrm{L}$ into each well of a microtiter plate containing $100 \mu \mathrm{L}$ of self-assembled NSAID-peptide (2-0.5\% w/v) prepared as described above. Control wells included bacteria treated with PBS, as the negative control (100\% survival) and $2 \% \mathrm{w} / \mathrm{v}$ HPMC as an inert hydrogel to study the effect of gelation on bacterial viability. Inoculated microtiter plates were incubated for 24 hours in a Gallenkamp gyrorotary incubator $\left(37^{\circ} \mathrm{C}\right)$ and $20 \mu \mathrm{L}$ samples were taken from each well, serially diluted in PBS and transferred onto Müller Hinton agar plates for colony counting via the Miles and Misra method. Results were displayed as the mean $\left(\log _{10} \mathrm{CFU} / \mathrm{mL}\right)$ of four replicates.

\section{Cyclooxygenase Enzyme Inhibition Assay}

The anti-inflammatory activity of the NSAID-peptides $(1-2000 \mu \mathrm{M})$ were determined against both COX-1 and COX-2 enzymes using a COX Fluorescent Inhibitor Screening Assay Kit. Reagents used were supplied and prepared according to the kit protocol. Potassium hydroxide 
(KOH), DMSO, COX-1 (SC-560) and COX-2 (DuP-697) inhibitors were supplied ready for use. Assay buffer (x10) (final formulation: $100 \mathrm{mM}$ Tris-HCl, $\mathrm{pH}$ 8.0), heme, arachadonic acid (final concentration: $2 \mathrm{mM}$ ) were prepared as per kit instructions. The test plates (one plate per COX enzyme) were set up according to the kit protocol with triplicates for each NSAID-peptide concentration. The inhibitor/sample was incubated with the enzyme for 5 minutes at room temperature. $10 \mu \mathrm{L}$ of 10-acetyl-3, 7-dihydroxyphenoxazine (ADHP) was added followed by $10 \mu \mathrm{L}$ of arachidonic acid (reaction initiator). The plates were incubated for 2 minutes at room temperature and then read at an excitation wavelength of $530 \mathrm{~nm}$ and an emission wavelength of $585 \mathrm{~nm}$ using a FLUOstar Omega Fluorometer (BMG Labtech, Ortenberg, Germany) and Gen5 data analysis software (BioTek, Swindon, U.K.). IC $_{50}$ (concentration needed to inhibit COX activity by half) values were interpreted from activity curves ( $\log _{10}$ inhibitor vs normalized response) using GraphPad Prism 6 (GraphPad Software Inc, California, USA). The percentage inhibition of the COX enzymes was calculated by measurement of respective emission wavelengths (585nm) and using Equation 1.

\section{$\%$ Inhibition $=\frac{\lfloor\text { COX activity noinhibitor }-N S A I D / \text { peptide activity }\rfloor}{\text { COX activity noinhibitor }} \times 100$}

In each case, the background fluorescence was subtracted from each fluorescence value obtained. The percentage inhibition of the test inhibitors SC-560 and DuP-697 enabled a direct comparison to be made between the NSAID-peptide activity and that of a known inhibitor. NSAID only wells (( \pm -ibuprofen, indomethacin, $(\mathrm{S})-(+)$-naproxen: 1-50 $\mu \mathrm{M})$ were tested to determine whether or not conjugation of the NSAID to the peptide altered antiinflammatory activity/selectivity. All compounds were assayed in triplicate. 


\section{Hemolysis Assay}

The ability of NSAID-peptides to induce hemogolobin release from fresh equine erythrocytes was tested using a method previously outlined by our group [34]. $100 \mu \mathrm{L}$ of equine erythrocytes were treated with $100 \mu \mathrm{L}$ of NSAID-peptides for 1 hour at $37^{\circ} \mathrm{C}$. Control wells included $0.1 \%$ v/v Triton X-100 (100\% hemolysis, positive control) and PBS (0\% hemolysis, negative control). Following incubation the erythrocytes were centrifuged at $1000 \mathrm{~g}$ and aliquots of the supernatant used to determine hemoglobin released in a fresh 96-well microtiter plate read at $405 \mathrm{~nm}$ using a Tecan Sunrise plate reader (Tecan UK Ltd, Reading, U.K.) and Equation 2 below. Results are reported as the mean of six replicates.

$$
\% \text { Hemolysis }=\frac{A b s 405 n m \text { Peptide }-A b s 405 n m P B S}{A b s 405 n m 0.1 \% \text { TritonX }-A b s 405 m P B S} \times 100
$$

\section{Cell Viability Assay}

Cell cytotoxicity was assessed using murine fibroblast subcutaneous connective tissue NCTC clone 929 (ATCC CCL 1). Cells were cultured in Minimum Essential Medium (MEM) containing phenol red with Earle's Salts and L-glutamine, supplemented with $10 \%$ horse serum and $1 \%$ penicillin and streptomycin (Invitrogen, Paisley, U.K.). Cells were grown at $37{ }^{\circ} \mathrm{C}$ and $5 \% \mathrm{CO}_{2}$ and subcultured at $80-90 \%$ confluency. Subculturing involved removal of spent media, washing with sterile PBS and detachment of cell monolayers with $0.05 \%$ trypsin/ 0.53 mM EDTA.4Na solution (Invitrogen, Paisley, U.K.). Cells were cultured until at least third passage and inoculated at $1 \times 10^{4}$ cells per well in 96-well microtiter plate and incubated for 24 hours. The media was then removed and the cells exposed to $100 \mu \mathrm{L}$ of a range of NSAID-peptide samples for 24 hours. Control wells included PBS (100\% viability, negative 
control) and $70 \%$ ethanol treated cells (100\% kill, positive control). Following exposure to NSAID-peptides, cell viability was assessed using a $10 \% \mathrm{v} / \mathrm{v}$ solution of alamarBlue ${ }^{\circledR}$ diluted in supplemented MEM and allowed to develop for 10 hours. Absorption was measured at 570 nm using a Tecan Sunrise plate reader. Cell viability was calculated using Equation 3 below and reported as the mean of six replicates.

$$
\% \text { viability }=100-\left(\frac{A b s 570 \mathrm{~nm} \text { Peptide }- \text { Abs570nm PBS }}{\text { Abs570nm 70\% Ethanol }- \text { Abs570nm PBS }} \times 100\right)
$$

\section{Statistical Analysis}

Statistical analyses were performed using Microsoft Excel 2013 and GraphPad Prism 6.

Standard deviations were obtained at each concentration of NSAID-peptide tested based on six replicates for quantitative bacterial viability assays and mean values obtained. For cell cytotoxicity assays standard deviations and mean values were also obtained from six replicates at each concentration. Statistical analyses were employed using a Kruskal-Wallis test, with a Dunn's multiple comparisons test used to identify individual differences between the reduction in bacterial viability for each NSAID-peptide hydrogel relative to the negative PBS control. A Kruskal-Wallis test, followed by a Dunn's multiple comparisons test, was also utilized for statistical analysis of tissue culture cytotoxicity data by comparison of percentage viability for the NSAID-peptides employed to the PBS negative control (100\% viability). Hemolysis data was compared by the same statistical method with percentage hemolysis compared to the PBS, negative, non-hemolytic, control ( $0 \%$ hemolysis). Non-parametric Kruskal-Wallis tests were employed rather than parametric Analysis of Variance (ANOVA) 
as data was shown to be non-normally distributed using the Kolmogorov and Smirnov method. In all cases a probability of $\mathrm{p}<0.05$ denoted significance.

Results and Discussion

Gel Inversion Assay

A variety of methods exist to successfully induce peptide hydrogelation including $\mathrm{pH}$, thermal (heat-cool) and enzymatic means. In order to ensure the conditions that mediate hydrogelation were replicated as closely as possible we decided to utilize a $\mathrm{pH}$-triggered approach, to a final physiological $\mathrm{pH}$ of 7.4, at room temperature and using L-amino acid isomers.

Diastereoisomers of NSAID peptides have previously demonstrated different behavior in relation to self-assembly and hydrogelation [25]. All NSAID-peptides formed clear solutions at $\mathrm{pH} 9$ and above. Hydrogelation is driven by subsequent titration of acid, highlighting the role of the terminal carboxylic acid moiety in self-assembly [18].

To enable hydrogelation a critical balance is required between molecular hydrophilicity and hydrophobicity with the surrounding medium, primarily water, providing excellent capacity for hydrogen bonding $[35,36]$. NpxFFKK demonstrated the greatest capacity to form stable hydrogels possessing a critical gelation concentration of $0.4 \% \mathrm{w} / \mathrm{v}$ (Table 2, Figure 2c and S7). IbuFFKK was unable to form hydrogels in standard deionized water $\left(\mathrm{H}_{2} \mathrm{O}\right)$ instead forming an opaque, white precipitate (Figure S4). Interestingly IbuFFKK formed a transparent soft gel at $2 \% \mathrm{w} / \mathrm{v}$ using deuterated water $\left(\mathrm{D}_{2} \mathrm{O}\right)$ (Figure $2 \mathrm{a}$ and $\left.\mathrm{S} 5\right)$. This phenomenon may be due to increased hydrogen bond strength between deuterated hydrogen and electron donors (amines, carbonyl and carboxylic acid groups) present within the NSAID-peptide primary structure $[37,38]$. The number of hydrogen bonds per molecule of water is also higher for deuterated water compared to standard water [38]. As hydrogel formation is a delicate balance between solubilization and precipitation the use of deuterated water may favor increased hydrogen 
bond formation and improved solubilization for IbuFFKK resulting in formation of a clear hydrogel at $2 \% \mathrm{w} / \mathrm{v}$. IndFFKK was able to form a self-supporting supramolecular hydrogel at $1.5 \% \mathrm{w} / \mathrm{v}$ (Figure S6) becoming an increasingly white and opaque hydrogel as the concentration increased to $2 \% \mathrm{w} / \mathrm{v}$ (Figure $2 \mathrm{~b}$ ).

\section{Microscopy}

Transmission electron microscopy (TEM) and cryogenic scanning electron microscopy (cryoSEM) were utilized to examine the nanoscale architecture of the molecular assemblies. NpxFFKK hydrogels were found to be composed of nanofibers that entangled to form an entangled network (Figure 3c and S8c and S10c). Naproxen has previously demonstrated ability to self-assemble into supramolecular hydrogels with nanofibrous architecture when attached to a variety of peptidomimetic molecules including peptide amphiphiles and $\beta$ peptides [21,39]. By contrast $2 \% \mathrm{w} / \mathrm{v}$ IbuFFKK forms less uniform, non-fibrous structures in the presence of deuterated water (Figure 3a and S8a and S10a). Interactions between these nanoparticles and the surrounding solvent are sufficient to form a self-supporting supramolecular hydrogel as defined by the vial inversion assay [30]. However rheological analysis, detailed below, confirms that the resulting material more closely resemble a viscous liquid with surfactant-like properties. Cryo-SEM images for $2 \% \mathrm{w} / \mathrm{v}$ IbuFFKK in standard deionized water show the presence of a non-uniform fibers (Figure S9a) and particles (Figure $\mathrm{S} 9 \mathrm{~b})$ that result in formation of a white precipitate. IndFFKK formed short nanotape-like structures (Figure 3b and S8b and S10b) where hydrophobic segments are packed tightly away from the aqueous interface. These appear less uniform, forming areas of dense pockets, compared to the nanofibrous architecture of NpxFFKK. These networks of, varying morphologies, are responsible for the immobilization of surrounding solvent molecules resulting in gel formation [21]. The structural morphologies correlate well to the oscillatory rheological profiles, most notably the storage moduli, as discussed further below. 
However, the molecular-level understanding of the exact mechanism of peptide gelation kinetics remains unclear despite extensive research and warrants further investigation within the field [40]. It should also be noted that analysis of TEM images of gels, such as morphology of fibers, may not accurately represent the gel network and so should be done with caution. TEM images are of dried gels, whereas tests such as rheology are carried out on wet gels. Therefore, the structures observed by SEM could be due to drying effects $[41,42]$.

\section{Fourier Transform Infrared Spectroscopy}

The secondary structures of NSAID-peptide nanostructures were determined by Fourier Transform Infrared (FTIR) spectroscopy. All FTIR studies were conducted in deuterated solvents, acknowledging the difficulty encountered using standard water due to strong absorbance within the amide I region $\left(1700-1600 \mathrm{~cm}^{-1}\right)$ [21]. The amide I band is generated through stretching of the $\mathrm{C}=\mathrm{O}$ bond and its participation in hydrogen bonding provides an insight into peptide secondary structures. All NSAID-peptides were studied at or above critical gelation concentrations $(2 \% \mathrm{w} / \mathrm{v})$. NpxFFKK demonstrated the most predominant $\beta$ sheet secondary structure characterized by a strong reduction in transmittance at $1630 \mathrm{~cm}^{-1}$ (Figure S11) [43]. This trough is less pronounced for IndFFKK and particularly IbuFFKK owing to less uniform nanoparticle and nanotape structures respectively. However, they both possess a shoulder-like reduction in transmittance at $1679 \mathrm{~cm}^{-1}$ possibly linked to the presence of antiparallel $\beta$-sheets (Figure S11). Increased concentration of NpxFFKK, from 0.5 to $2.0 \%$ $\mathrm{w} / \mathrm{v}$, correlated to a respective reduction in transmittance at 1630 and $1679 \mathrm{~cm}^{-1}$ owing to a greater presence of $\beta$-sheet secondary structures and more rigid hydrogels at $2 \% \mathrm{w} / \mathrm{v}$ NpxFFKK (Figure S12). However, interpreting this data for short dipeptide molecules is often difficult as has been seen with other ultrashort peptide hydrogels. 


\section{Oscillatory Rheology}

Oscillatory rheology was utilized to study the viscoelastic properties of $2 \%$ w/v selfassembled NSAID-peptide hydrogels (Figure 4). The frequency dependence of their storage $\left(\mathrm{G}^{\prime}\right)$ and loss moduli $\left(\mathrm{G}^{\prime \prime}\right)$ were measured using a dynamic frequency sweep, varying the oscillation frequency (1-100 $\left.\mathrm{rad} \mathrm{s}^{-1}\right)$ at a constant oscillation amplitude $(0.0003 \%)$ and temperature $\left(25^{\circ} \mathrm{C}\right)$.

NpxFFKK exhibits viscoelastic properties of a solid-like material as observed by the maximal storage modulus $\left(\mathrm{G}^{\prime}:\right.$ $398 \mathrm{~Pa}$ ) being ten times larger than the maximal loss modulus $\left(\mathrm{G}^{\prime \prime}\right.$ : $\sim 39.8 \mathrm{~Pa}$ ). They are independent of frequency and demonstrate good tolerance to external shear force. NpxFFKK has the highest mean storage modulus and greatest gel strength of the NSAID-peptides $\left(\mathrm{G}^{\prime}:\right.$ 398). Its $\mathrm{G}^{\prime}$ and $\mathrm{G}^{\prime \prime}$ are comparable to that of the widely reported FmocFF hydrogels [44]. A larger conjugate system, conferred by the presence of naproxen in NpxFFKK (Figure 1c), enables stronger $\pi-\pi$ and van der Waals' intermolecular interactions between NpxFFKK molecules and allows longer fibers and more entangled arrangement of nanofibers as observed via microscopy (Figure 3c). Similarly IndFFKK is capable of forming a stable hydrogel at $2 \% \mathrm{w} / \mathrm{v}$ possessing a mean $\mathrm{G}^{\prime}$ of $25.1 \mathrm{~Pa}$ and a mean $\mathrm{G}^{\prime \prime}$ of $6.6 \mathrm{~Pa}$. Reduced $\mathrm{G}^{\prime}$ and $\mathrm{G}^{\prime \prime}$ in comparison to NpxFFKK is explained by formation of shorter nanotape architectures rather than longer nanofiber structures observed in NpxFFKK gels (Figure 3b and $\mathrm{S} 8 \mathrm{~b}$ and $\mathrm{S} 10 \mathrm{~b})$. Despite forming what appears to be a self-supporting hydrogel upon inversion at a concentration of $2 \% \mathrm{w} / \mathrm{v}$ in deuterated water (Figure $2 \mathrm{a}$ ), rheology confirms IbuFFKK does not form a hydrogel with significant mechanical rigidity. A high dependence on frequency shows that it is behaving as a liquid rather than a gel, as gels show no dependence on frequency. This is due to reduced aromatic-aromatic $(\pi-\pi)$ interactions provided by the terminal isopropyl-substituted phenyl group of IbuFFKK (Figure 1a) that are only sufficient to allow formation of non-uniform nanoparticle structures. This result is 
similar to that observed previously by the Xu group where IbuFF demonstrated a low $\mathrm{G}^{\prime}$ value of only $13 \mathrm{~Pa}[25]$.

\section{Bacterial Susceptibility}

The antibacterial activity of NSAID-peptides was tested using a viable count assay after 24 hour exposure to varying concentrations of NSAID-peptides. Clinically relevant bacterial strains, implicated in a variety of antibiotic resistant nosocomial infections (biomaterial and wounds), were selected, namely: methicillin resistant S. epidermidis (ATCC 25984), S. aureus (ATCC 6584), P. aeruginosa (PAO1) and E. coli (ATCC 11303). All NSAID-peptides demonstrated broad-spectrum antibacterial activity (Gram-positive and Gram-negative) (Figure 5 and 6 and S13 and S14). The mechanism of action of our NSAID-peptides is likely to follow the key parameters of antimicrobial peptide activity, namely hydrophobic bulk and cationic charge enabling interaction with bacterial membranes [13]. The addition of two units of cationic charge, in this case lysine, to an ultrashort (less than seven amino acid units) peptidomimetic sequence is sufficient to confer antimicrobial activity [34]. As previously demonstrated by our group, the $\varepsilon$-amino group of lysine has the ability to interact with negatively charged bacterial membranes and their anionic hydroxylated phospholipids resulting in detergent-like effects, cell lysis and death [18].

At least a three $\log _{10} \mathrm{CFU} / \mathrm{mL}(99.9 \%)$ reduction in viable bacteria, commonly employed as a threshold for bactericidal efficacy, was observed for each NSAID-peptide at concentrations of $0.5 \% \mathrm{w} / \mathrm{v}$ and above [45]. Statistical analysis, however, shows NpxFFKK to be the only NSAID-peptide that is significantly bactericidal against all four isolates with improved activity correlating to increased concentration. For example, significant bacterial kill was achieved at concentrations of $1.5 \% \mathrm{w} / \mathrm{v}$ and above for Gram-negative P. aeruginosa and $E$. coli; $1.0 \%$ and above for Gram-positive S. epidermidis and $0.5 \% \mathrm{w} / \mathrm{v}$ and above for S. aureus. 
A reduction greater than $5.5 \log _{10} \mathrm{CFU} / \mathrm{mL}$ was obtained for $2 \% \mathrm{w} / \mathrm{v} \mathrm{NpxFFKK}$ against $S$. epidermidis and S. aureus. The improved antimicrobial efficacy of NpxFFKK may be related to its ability to form a viscoelastic hydrogel of uniform nanofibrous architecture. Recent studies have suggested that that molecular folding, structural conformation, assembly state and bulk mechanical properties are important considerations for the rational design of antimicrobial selective hydrogels $[17,46,47]$. We propose our NpxFFKK hydrogel acts similarly to the dimethyldecylammonium chitosan-graft-poly(ethylene glycol) methacrylate (DMDC-Q-g-EM) 'anion sponge' developed by the Chan-Park group [48]. Based on this theory, the nanoporous architecture of cationic NpxFFKK allows increased interactions, termed 'suctioning,' with anionic constituents of the bacterial membrane. Therefore the hydrogel acts as a molecular sponge resulting in bacterial membrane disruption and cell death.

The inclusion of cationic charge density within the hydrogel matrix is a key parameter for selective antimicrobial activity as demonstrated by the range of $\beta$-hairpin hydrogels (MAX, PEP6R and MARG) developed by the Schneider group [49,50,51] Hydrogelation alone is not sufficient to bestow antimicrobial activity, for example by restricting the diffusion of chemical messengers and nutrients. This is confirmed by the observed lack of efficacy of nonionic $2 \% \mathrm{w} / \mathrm{v}$ hydroxypropyl methylcellulose (HPMC) against all bacterial isolates. This is an unsurprising observation given that bacteria commonly prefer to exist and successfully survive within a surface-attached, extracellular polymeric matrix granted by the biofilm phenotype. As the Dong group hypothesized for their multi-domain peptides, the combined effect of localized cationic charge on the hydrogel surface and the porous network of crosslinked nanofibers (Figure 3c and S8c and S10c) are likely to be responsible for the improved antimicrobial efficacy of NpxFFKK $[32,47]$. Our ultrashort peptide motif possesses improved antimicrobial efficacy compared to related peptide-based strategies in the literature at a reduced polymer size and increased ease of synthesis. 
Chronic wounds fail to heal and are characterized by persistent inflammation due in part to the presence of bacterial biofilms [52]. Research by Wolcott and Rhodes also demonstrated that the presence of bacterial infection in chronic wounds perpetuates a destructive level of inflammation [53]. Treatments active against resistant bacteria allowed non-healable, chronic wounds to heal. They concluded that topical agents with the ability to disrupt biofilm forming microorganisms should be central to the treatment of chronic wounds [54]. Previous work by our group demonstrates the significant efficacy of the FFKK-OH peptide motif against biofbacterial isolates. They may have a significant clinical benefit for the treatment of chronic infected wounds [18]. Whilst NSAIDs have recently been demonstrated to possess antibacterial activity alone by specifically targeting DNA Clamp, a key bacterial protein involved in multiplication, its inclusion within our motif is primarily to provide potential antiinflammatory, analgesic and self-assembly characteristics [55]. The benefits of NSAIDs as antibiotic therapy in their own right have to be verified clinically. Such studies provide hope to extend the currently available antibiotic formulary utilizing a readily available and licensed group of drugs.

These results may inform future strategies whereby the host immune response is controlled in combination with antimicrobial and antibiofilm activity. For example IDR-1018, a synthetic variant of the host defense peptide LL-37, has an ability to inhibit biofilm formation in combination with immunomodulatory effects which prevent tissue damage [56]. Although IDR-1018 did not display an ability to self-assemble into supramolecular structures the Hancock group did demonstrate antibiofilm peptides could be used to control mediators of the immune response, including stimulating monocyte chemoattractant protein (MCP-1) and inhibiting lipopolysaccharide induced interleukin-1 $\beta$ (IL-1 $\beta$ ) production in peripheral blood mononuclear cells [57]. 
Cyclooxygenase Enzyme Inhibition

We performed in vitro inhibition assays for both $\mathrm{COX}-1$ and $\mathrm{COX}-2$ in the presence of varying concentrations of NSAID-peptides. Molecular modeling, utilizing the crystal structure of COX enzymes, has previously shown that the NSAID carboxylate end is available for peptide modification due to the large open space in the structure of COX [46,58]. Addition of the peptide sequence FFKK-OH to the NSAID motif increases respective IC $_{50}$ values relative to NSAID only values. However, the NSAID-peptide motifs retain significant inhibitory activity with $\mathrm{IC}_{50}$ values within the $\mu \mathrm{M}$ range. For example, NpxFFKK exhibits $\mathrm{IC}_{50}$ values of 204.20 $\mu \mathrm{M}$ and 73.47 $\mu \mathrm{M}$ against COX-1 and COX-2 respectively compared with naproxen only values of $13.26 \mu \mathrm{M}(\mathrm{COX}-1)$ and $8.365 \mu \mathrm{M}(\mathrm{COX}-2)$ (Figure S15). NSAID-peptides also demonstrate increased selectivity for inhibiting COX-2 compared to NSAID alone. Selectivity (S) values, related to the ratio of $\mathrm{IC}_{50} \mathrm{COX}-1$ : $\mathrm{IC}_{50} \mathrm{COX}-2$, are highest for NpxFFKK $(S=2.78)$ compared to naproxen only $(S=0.19)$. This correlates to previous work on NSAID-peptide hydrogelators where it was proven that addition of a peptide moiety increased COX-2 selectivity [25,26]. Replacing L-amino acid enantiomers with their respective D-forms may increase inhibition of COX-2 further [46]. Selective COX-2 inhibition is preferred clinically, especially for systemic administration of NSAIDs, due to a reduction in renal and gastrointestinal side effects linked to COX-1 inhibition but may also have potential value in the chronic wound environment [59]. Studies have shown that upon degradation, the pharmaceutical efficacy of NSAIDs in theory should be maintained and pharmacological activity exhibited until the hydrogel has completely degraded. Therefore an extended profile of anti-inflammatory activity should be possible [60].

COX-2 and its enzymatic product prostaglandin E2 $\left(\mathrm{PGE}_{2}\right)$ demonstrate an important role in the early acute host response to stimuli such as wounds and are responsible for the 
upregulation of inflammatory mediators. Separate studies in murine and rat wound models by Blomme and Futagmi showed a significant induction of COX-2 expression after 12 hours, peaking three days after injury $[61,62]$. However within chronic wounds, COX-2 has recently been associated with the unwanted development of scar tissue in the latter stages of adult wound repair $[63,64]$. Therefore NSAID-peptide conjugates with increased selectivity for COX-2 inhibition may be of benefit in the chronic stages of wound healing, replicating fetal wound healing where scarless healing is linked to a reduced inflammatory response [64]. Despite this there is an appreciation that wound healing is a complex pathway and the exact role of multiple inflammatory mediators (cytokines, macrophages, matrix metalloproteinases) has not yet been fully elucidated [6]. In particular, the diverse nature of the immune and inflammatory response to foreign medical implants favors the use of corticosteroids, rather than NSAIDs, due to their broad-spectrum of activity against inflammatory mediators such as leukotrienes [65]. NSAID-peptides may serve a greater purpose within chronic wound healing, providing localized pain relief, antimicrobial and anti-inflammatory activity. Removal of an avascular fibrous capsule that surrounds implanted medical devices may be promoted by inclusion of pro-angiogenic factors including vascular endothelial growth factor (VEGF). Our nanomaterials have the potential to act as a drug delivery platform for the design of future medical device coatings incorporating such factors [11]. The effect of NSAID-peptides nanostructures on mediators of the immune response. The overall wound healing pathway and foreign body response to medical implants warrants further clinical investigation. A more obvious therapeutic benefit for NSAID-peptides is provided via inhibition of nociception and pain receptors linked to $\mathrm{COX}[66]$. Reduction in pain can be linked to improvement in wound healing and patient prognosis [67]. 


\section{Hemolysis and Cell Viability}

To evaluate cell biocompatibility of NSAID-peptides, they were incubated with an International Standard (ISO) cell line utilized for biomaterial testing (NCTC 929 murine fibroblast subcutaneous connective tissue). Fibroblasts are appropriate as they are one of the major cell types involved both in wound healing and adherence to implanted medical devices [11]. The results suggest that NSAID-peptide nanomaterials are biocompatible and may be suitable for use within a range of biomaterial and topical applications. No significant reduction was observed in cell viability after 24 hour exposure to varying concentrations of NSAID-peptides (20-500 mM) utilizing an alamarBlue ${ }^{\circledR}$ cell viability assay (Figure 7). Cationic NSAID-peptides demonstrate reduced toxicity against mammalian cells due to inherent differences in the membrane potential gradient and lipid composition of bacterial and mammalian cell membranes. Eukaryotic cells are composed of zwitterionic lipids (sterols, cholesterol, phosphatidylcholine, sphingomyelin) whereas bacterial cells are derived from anionic phospholipids [68]. Positively charged NSAID-peptide therefore interact preferentially with negatively charged bacterial cell membranes as confirmed by a hemolysis assay (Figure S16), commonly utilized to determine the membrane selectivity of antimicrobial peptides $[18,32,69]$. No significant hemolysis was observed upon NSAID-peptide (20-500 $\mathrm{mM}$ ) exposure to equine erythrocytes relative to a PBS negative control.

\section{Conclusions}

In conclusion, we have created a new class of NSAID-peptides with the ability to form defined nanostructures with multiple biofunctional properties (antimicrobial, antiinflammatory, hydrogel forming). NpxFFKK displays particular promising forming a viscoelastic biocompatible hydrogel with improved COX-2 selectivity and the ability to target antimicrobial resistant bacteria implicated in the most severe nosocomial infections. These hydrogel formulations may be beneficial in the treatment of chronic infected wounds, where a 
heightened inflammatory response to infection leads to impaired healing. Their ultrashort, low molecular weight structure makes their synthesis more amenable to cost-effective upscale by the pharmaceutical industry compared to larger peptides and proteins. This work provides an example of multifunctional peptide hydrogelators that will contribute to the development of future biofunctional nanomaterial therapies, especially within biomaterial applications (wound dressings, medical implants, prostheses), thereby increasing the available treatment options to clinicians and patients and limiting the increasing threat of antimicrobial resistance.

\section{References}

[1] O'Neill J. The Review on Antimicrobial Resistance: UK Government Report. The Review on Antimicrobial Resistance 2015.

[2] Centre for Disease control (CDC). Data from the National Hospital Discharge Survey. Available: http://www.cdc.gov/nchs/data/nhds/4procedures/2010pro_numberpercentage.pdf. 2010.

[3] Astagneau P, Rioux C, Golliot F, Brucker G, INCISO Network Study Group. Morbidity and mortality associated with surgical site infections: results from the 1997-1999 INCISO surveillance. J Hosp Infect 2001;48:267-274.

[4] Guo S, Dipietro LA. Factors affecting wound healing. J Dent Res 2010;89:219-229.

[5] Gottrup F. A specialized wound-healing center concept: importance of a multidisciplinary department structure and surgical treatment facilities in the treatment of chronic wounds. Am J Surg 2004;187:38S-43S.

[6] Menke NB, Ward KR, Witten TM, Bonchev DG, Diegelmann RF. Impaired wound healing. Clin Dermatol 2007;25:19-25.

[7] Konturek PC, Brzozowski T, Konturek SJ, Kwiecien S, Dembinski A, Hahn EG. Influence of bacterial lipopolysaccharide on healing of chronic experimental ulcer in rat. Scand J Gastroenterol 2001;36:1239-1247. 
[8] Ståhle M. Wound repair and antimicrobial peptides. In: Hiemstra PS, Zaat SAJ, editors. Antimicrobial Peptides and Innate ImmunityBasel: Springer, 2013. p. 123-129.

[9] Krischak GD, Augat P, Claes L, Kinzl L, Beck A. The effects of non-steroidal antiinflammatory drug application on incisional wound healing in rats. J Wound Care 2007;16:76-78.

[10] Hamilton SM, Bayer CR, Stevens DL, Bryant AE. Effects of selective and nonselective nonsteroidal anti-inflammatory drugs on antibiotic efficacy of experimental group A streptococcal myonecrosis. J Infect Dis 2014;209:1429-1435.

[11] Morais JM, Papadimitrakopoulos F, Burgess DJ. Biomaterials/tissue interactions: possible solutions to overcome foreign body response. AAPS J 2010;12:188-196. [12] Price P, Fogh K, Glynn C, Krasner DL, Osterbrink J, Sibbald RG. Why combine a foam dressing with ibuprofen for wound pain and moist wound healing? Int Wound J 2007;4 Suppl $1: 1-3$

[13] Laverty G, Gorman SP, Gilmore BF. The potential of antimicrobial peptides as biocides. Int J Mol Sci 2011;12:6566-6596.

[14] Laverty G, Gorman SP, Gilmore BF. Antimicrobial peptide incorporated poly(2hydroxyethyl methacrylate) hydrogels for the prevention of Staphylococcus epidermidisassociated biomaterial infections. J Biomed Mater Res A 2012;100:1803-1814.

[15] Cleophas RT, Sjollema J, Busscher HJ, Kruijtzer JA, Liskamp RM. Characterization and activity of an immobilized antimicrobial peptide containing bactericidal PEG-hydrogel. Biomacromolecules 2014;15:3390-3395.

[16] Xie Z, Aphale NV, Kadapure TD, Wadajkar AS, Orr S, Gyawali D, et al. Design of antimicrobial peptides conjugated biodegradable citric acid derived hydrogels for wound healing. J Biomed Mater Res A 2015;103:3907-3918. 
[17] Ng VW, Chan JM, Sardon H, Ono RJ, Garcia JM, Yang YY, et al. Antimicrobial hydrogels: a new weapon in the arsenal against multidrug-resistant infections. Adv Drug Deliv Rev 2014;78:46-62.

[18] Laverty G, McCloskey AP, Gilmore BF, Jones DS, Zhou J, Xu B. Ultrashort Cationic Naphthalene-Derived Self-Assembled Peptides as Antimicrobial Nanomaterials.

Biomacromolecules 2014.

[19] Webber MJ, Matson JB, Tamboli VK, Stupp SI. Controlled release of dexamethasone from peptide nanofiber gels to modulate inflammatory response. Biomaterials 2012;33:68236832.

[20] Zhao F, Ma ML, Xu B. Molecular hydrogels of therapeutic agents. Chem Soc Rev 2009;38:883-891.

[21] Majumder J, Das MR, Deb J, Jana SS, Dastidar P. beta-Amino acid and amino-alcohol conjugation of a nonsteroidal anti-inflammatory drug (NSAID) imparts hydrogelation displaying remarkable biostability, biocompatibility, and anti-inflammatory properties. Langmuir 2013;29:10254-10263.

[22] Ryan DM, Anderson SB, Senguen FT, Youngman RE, Nilsson BL. Self-assembly and hydrogelation promoted by F5-phenylalanine. Soft Matter 2010;6:475-479.

[23] Draper ER, Morris KL, Little MA, Raeburn J, Colquhoun C, Cross ER, et al. Hydrogels formed from Fmoc amino acids. Cryst Eng Comm 2015;17:8047-8057.

[24] Yang Z, Liang G, Ma M, Gao Y, Xu B. Conjugates of naphthalene and dipeptides confer molecular hydrogelators with high efficiency of hydrogelation and superhelical nanofibers. $\mathbf{J}$ Mater Chem 2007;17:850-854.

[25] Li JY, Kuang Y, Shi JF, Gao Y, Zhou J, Xu B. The Conjugation of Non-steroidal Antiinflammatory Drugs (NSAID) to Small Peptides for Generating Multifunctional Supramolecular Nanofibers/Hydrogels. Beilstein J Org Chem 2013;9:908-917. 
[26] Li JY, Li X, Kuang Y, Gao Y, Du X, Shi J, et al. Self-delivery multifunctional anti-HIV hydrogels for sustained release. Adv Healthc Mater 2013;2:1586-1590.

[27] Mensah AY, Houghton PJ, Dickson RA, Fleischer TC, Heinrich M, Bremner P. In vitro evaluation of effects of two Ghanaian plants relevant to wound healing. Phytother Res 2006;20:941-944.

[28] Gong C, Wu Q, Wang Y, Zhang D, Luo F, Zhao X, et al. A biodegradable hydrogel system containing curcumin encapsulated in micelles for cutaneous wound healing. Biomaterials 2013;34:6377-6387.

[29] Bhuniya S, Seo YJ, Kim BH. (S)-(+)-Ibuprofen-based hydrogelators: An approach toward anti-inflammatory drug delivery. Tetrahedron Lett 2006;47:7153-7156.

[30] Adams DJ, Butler MF, Frith WJ, Kirkland M, Mullen L, Sanderson P. A new method for maintaining homogeneity during liquid-hydrogel transitions using low molecular weight hydrogelators. Soft Matter 2009;5:1856-1862.

[31] Pogorelov AG, Selezneva II. Evaluation of collagen gel microstructure by scanning electron microscopy. Bull Exp Biol Med 2010;150:153-156.

[32] Jiang L, Xu D, Sellati TJ, Dong H. Self-assembly of cationic multidomain peptide hydrogels: supramolecular nanostructure and rheological properties dictate antimicrobial activity. Nanoscale 2015;7:19160-19169.

[33] Mateescu M, Baixe S, Garnier T, Jierry L, Ball V, Haikel Y, et al. Antibacterial PeptideBased Gel for Prevention of Medical Implanted-Device Infection. PLoS One 2015;10:e0145143.

[34] Laverty G, McLaughlin M, Shaw C, Gorman SP, Gilmore BF. Antimicrobial activity of short, synthetic cationic lipopeptides. Chem Biol Drug Des 2010;75:563-569.

[35] Chen L, Revel S, Morris K, C Serpell L, Adams DJ. Effect of molecular structure on the properties of naphthalene-dipeptide hydrogelators. Langmuir 2010;26:13466-13471. 
[36] McCloskey AP, Gilmore BF, Laverty G. Evolution of antimicrobial peptides to selfassembled peptides for biomaterial applications. Pathogens 2014;3:791-821.

[37] Cioni P, Strambini GB. Effect of heavy water on protein flexibility. Biophys J 2002;82:3246-3253.

[38] Soper AK, Benmore CJ. Quantum Differences between Heavy and Light Water. Phys Rev Lett 2008;101:065502.

[39] Conda-Sheridan M, Lee SS, Preslar AT, Stupp SI. Esterase-activated release of naproxen from supramolecular nanofibres. Chem Commun (Camb) 2014;50:13757-13760.

[40] Muro-Small ML, Chen J, McNeil AJ. Dissolution parameters reveal role of structure and solvent in molecular gelation. Langmuir 2011;27:13248-13253.

[41] Kolbel M, Menger FM. Hierarchical structure of a self-assembled xerogel. Chem Commun 2001:275-276.

[42] Estroff LA, Hamilton AD. Water gelation by small organic molecules. Chem Rev 2004;104:1201-1218.

[43] Jayawarna V, Richardson SM, Hirst AR, Hodson NW, Saiani A, Gough JE, et al. Introducing chemical functionality in Fmoc-peptide gels for cell culture. Acta Biomater 2009;5:934-943.

[44] Tang C, Smith AM, Collins RF, Ulijn RV, Saiani A. Fmoc-diphenylalanine selfassembly mechanism induces apparent pKa shifts. Langmuir 2009;25:9447-9453. [45] Pankey GA, Sabath LD. Clinical relevance of bacteriostatic versus bactericidal mechanisms of action in the treatment of Gram-positive bacterial infections. Clin Infect Dis 2004;38:864-870.

[46] Li J, Kuang Y, Gao Y, Du X, Shi J, Xu B. D-amino acids boost the selectivity and confer supramolecular hydrogels of a nonsteroidal anti-inflammatory drug (NSAID). J Am Chem Soc 2013;135:542-545. 
[47] Xu D, Jiang L, Singh A, Dustin D, Yang M, Liu L, et al. Designed supramolecular filamentous peptides: balance of nanostructure, cytotoxicity and antimicrobial activity. Chem Commun (Camb) 2015;51:1289-1292.

[48] Li P, Poon YF, Li W, Zhu HY, Yeap SH, Cao Y, et al. A polycationic antimicrobial and biocompatible hydrogel with microbe membrane suctioning ability. Nat Mater 2011;10:149156.

[49] Salick DA, Kretsinger JK, Pochan DJ, Schneider JP. Inherent antibacterial activity of a peptide-based beta-hairpin hydrogel. J Am Chem Soc 2007;129:14793-14799.

[50] Salick DA, Pochan DJ, Schneider JP. Design of an Injectable $\beta$-Hairpin Peptide Hydrogel That Kills Methicillin-Resistant Staphylococcus aureus. Adv Mater 2009;21:41204123.

[51] Veiga AS, Sinthuvanich C, Gaspar D, Franquelim HG, Castanho MA, Schneider JP. Arginine-rich self-assembling peptides as potent antibacterial gels. Biomaterials 2012;33:8907-8916.

[52] Grice EA, Segre JA. Interaction of the microbiome with the innate immune response in chronic wounds. Adv Exp Med Biol 2012;946:55-68.

[53] Wolcott RD, Rhoads DD, Bennett ME, Wolcott BM, Gogokhia L, Costerton JW, et al. Chronic wounds and the medical biofilm paradigm. J Wound Care 2010;19:45-6, 48-50, 52-3. [54] Wolcott RD, Rhoads DD. A study of biofilm-based wound management in subjects with critical limb ischaemia. J Wound Care 2008;17:145-8, 150-2, 154-5.

[55] Yin Z, Wang Y, Whittell LR, Jergic S, Liu M, Harry E, et al. DNA replication is the target for the antibacterial effects of nonsteroidal anti-inflammatory drugs. Chem Biol 2014;21:481-487.

[56] Mansour SC, de la Fuente-Nunez C, Hancock RE. Peptide IDR-1018: modulating the immune system and targeting bacterial biofilms to treat antibiotic-resistant bacterial infections. J Pept Sci 2015;21:323-329. 
[57] Haney EF, Mansour SC, Hilchie AL, de la Fuente-Nunez C, Hancock RE. High throughput screening methods for assessing antibiofilm and immunomodulatory activities of synthetic peptides. Peptides 2015;71:276-285.

[58] Duggan KC, Walters MJ, Musee J, Harp JM, Kiefer JR, Oates JA, et al. Molecular basis for cyclooxygenase inhibition by the non-steroidal anti-inflammatory drug naproxen. J Biol Chem 2010;285:34950-34959.

[59] Silverstein FE, Faich G, Goldstein JL, Simon LS, Pincus T, Whelton A, et al. Gastrointestinal toxicity with celecoxib vs nonsteroidal anti-inflammatory drugs for osteoarthritis and rheumatoid arthritis: the CLASS study: A randomized controlled trial. Celecoxib Long-term Arthritis Safety Study. JAMA 2000;284:1247-1255.

[60] Vemula PK, Li J, John G. Enzyme catalysis: tool to make and break amygdalin hydrogelators from renewable resources: a delivery model for hydrophobic drugs. J Am Chem Soc 2006;128:8932-8938.

[61] Futagami A, Ishizaki M, Fukuda Y, Kawana S, Yamanaka N. Wound healing involves induction of cyclooxygenase-2 expression in rat skin. Lab Invest 2002;82:1503-1513. [62] Blomme EA, Chinn KS, Hardy MM, Casler JJ, Kim SH, Opsahl AC, et al. Selective cyclooxygenase- 2 inhibition does not affect the healing of cutaneous full-thickness incisional wounds in SKH-1 mice. Br J Dermatol 2003;148:211-223.

[63] Wilgus TA, Vodovotz Y, Vittadini E, Clubbs EA, Oberyszyn TM. Reduction of scar formation in full-thickness wounds with topical celecoxib treatment. Wound Repair Regen $2003 ; 11: 25-34$.

[64] Wilgus TA, Bergdall VK, Tober KL, Hill KJ, Mitra S, Flavahan NA, et al. The impact of cyclooxygenase- 2 mediated inflammation on scarless fetal wound healing. Am J Pathol 2004;165:753-761.

[65] Kastellorizios M, Tipnis N, Burgess DJ. Foreign body reaction to subcutaneous implants: Mechanisms and therapeutic interventions. In: Lambris JD, Ekdahl KN, Ricklin D, Nilsson D, 
editors. Immune Responses to BiosurfacesSwitzerland: Springer International Publishing, 2015. p. 93-108.

[66] Bingham S, Beswick PJ, Blum DE, Gray NM, Chessell IP. The role of the cylooxygenase pathway in nociception and pain. Semin Cell Dev Biol 2006;17:544-554.

[67] McGuire L, Heffner K, Glaser R, Needleman B, Malarkey W, Dickinson S, et al. Pain and wound healing in surgical patients. Ann Behav Med 2006;31:165-172.

[68] Mason AJ, Marquette A, Bechinger B. Zwitterionic phospholipids and sterols modulate antimicrobial peptide-induced membrane destabilization. Biophys J 2007;93:4289-4299.

[69] Laverty G, McCloskey AP, Gorman SP, Gilmore BF. Anti-biofilm activity of ultrashort cinnamic acid peptide derivatives against medical device-related pathogens. J Pept Sci 2015;21:770-778.

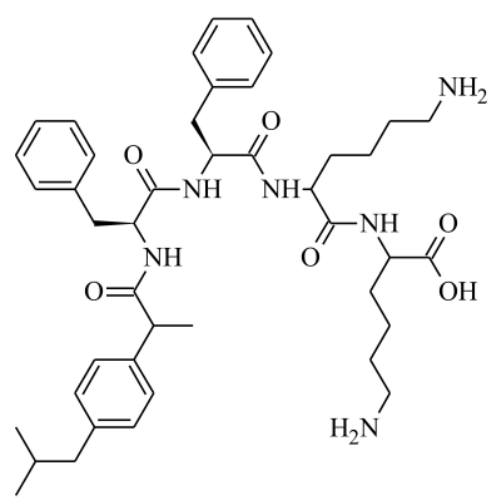

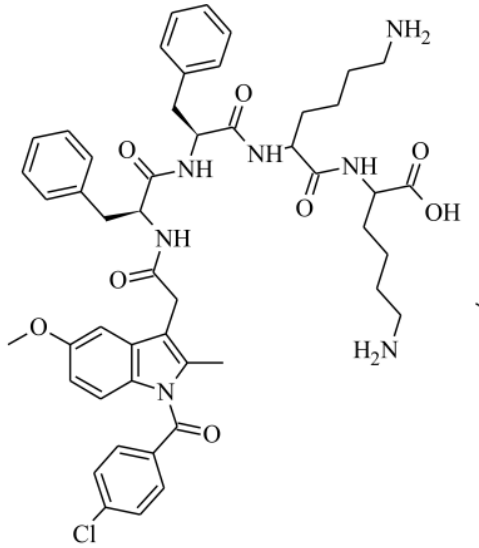

$\mathrm{b}$

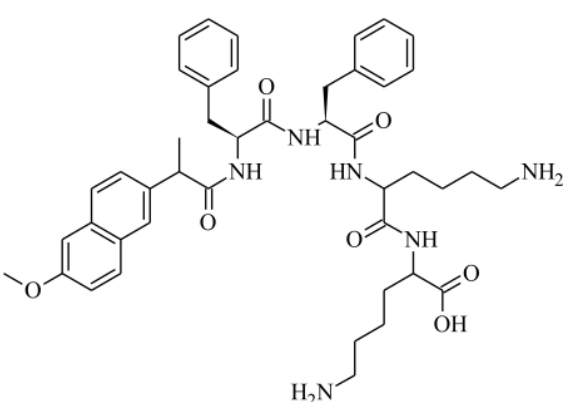

Figure 1. Chemical structures of NSAID-peptides investigated: (a) IbuFFKK, (b) IndFFKK, (c) NpxFFKK. 
a)

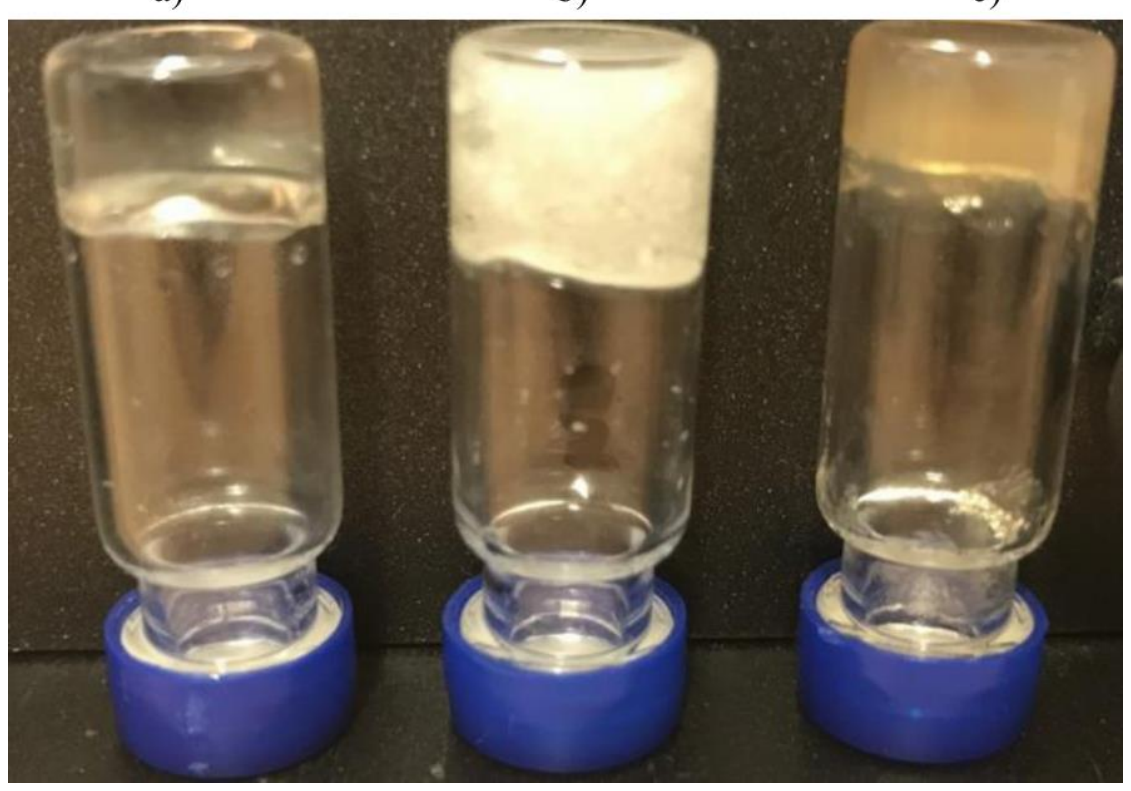

Figure 2. Gel inversion assay for $2 \% \mathrm{w} / \mathrm{v} \mathrm{pH} 7.4$ (a) IbuFFKK, $\mathrm{D}_{2} \mathrm{O}$ primary vehicle, (b) IndFFKK, $\mathrm{H}_{2} \mathrm{O}$ primary vehicle (c) $\mathrm{NpxFFKK}, \mathrm{H}_{2} \mathrm{O}$ primary vehicle.

a)

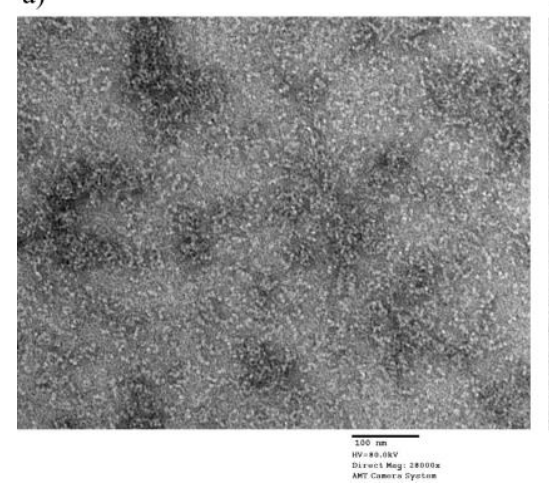

b)
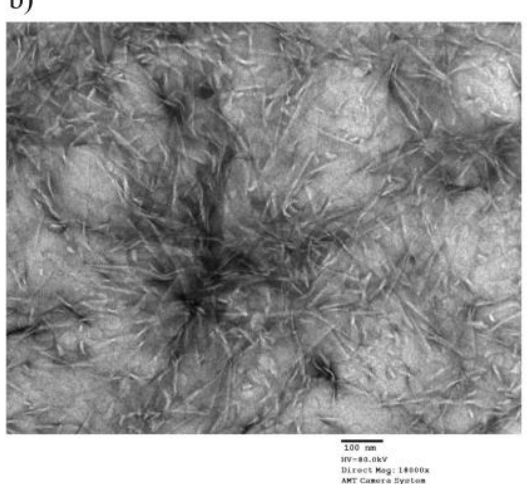

c)

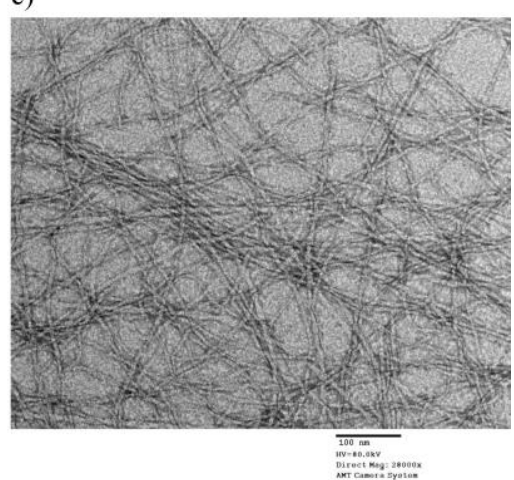

Figure 3. Transmission electron microscopy (TEM) images of $2 \% \mathrm{w} / \mathrm{v}$ (a) IbuFFKK $(28,000 \mathrm{x}$, $\left.\mathrm{D}_{2} \mathrm{O}\right)$, (b) IndFFKK $\left(18,000 x, \mathrm{H}_{2} \mathrm{O}\right)$, (c) NpxFFKK $\left(28,000 x, \mathrm{H}_{2} \mathrm{O}\right)$. 


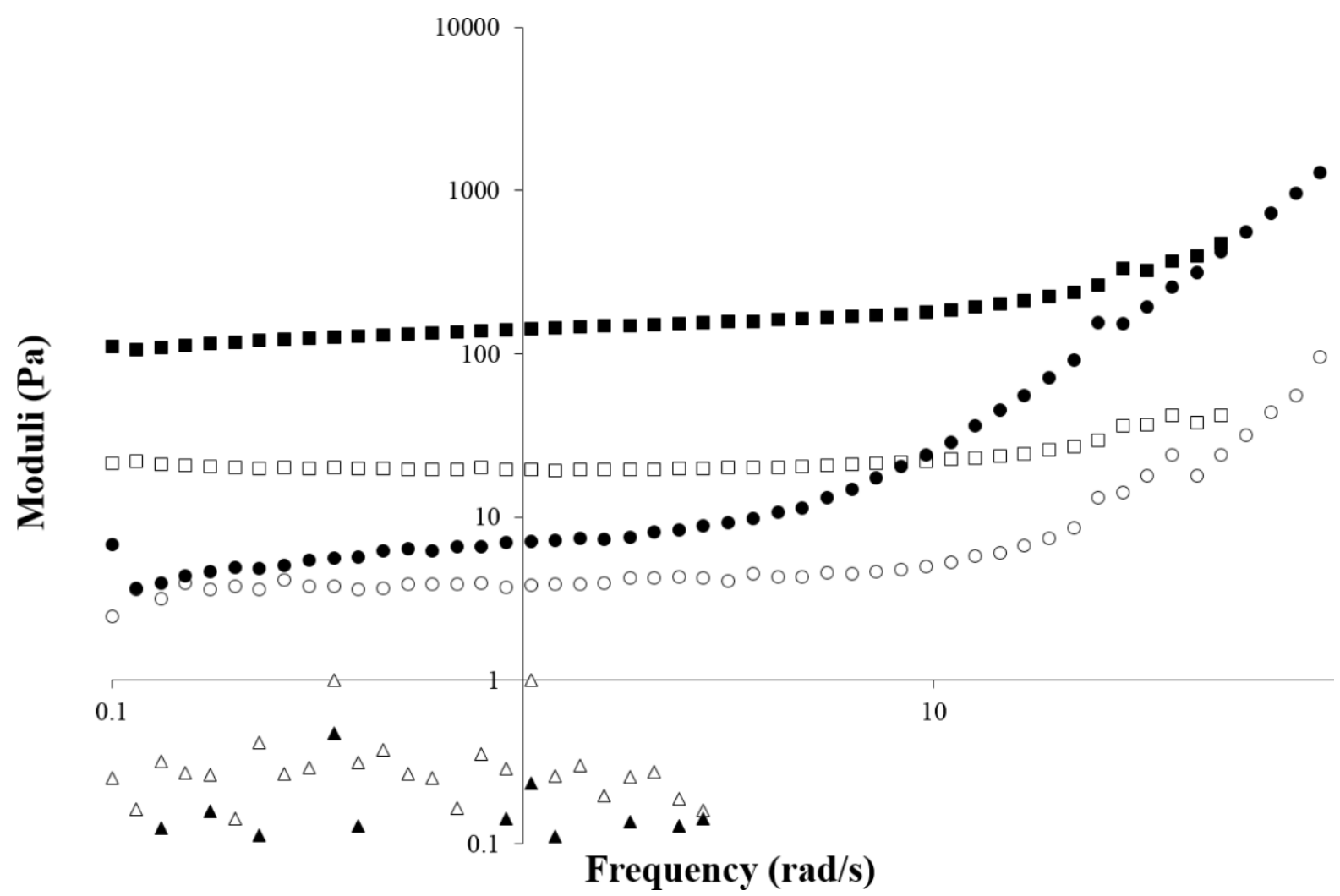

Figure 4. Oscillatory frequency sweep $2 \%$ w/v NSAID-peptides. Key: black triangle: $\mathrm{G}^{\prime}$

IbuFFKK, white triangle: G" IbuFFKK, black circle: G' IndFFKK, white circle: G" IndFFKK, black square: G' NpxFFKK, white square: G" NpxFFKK. 


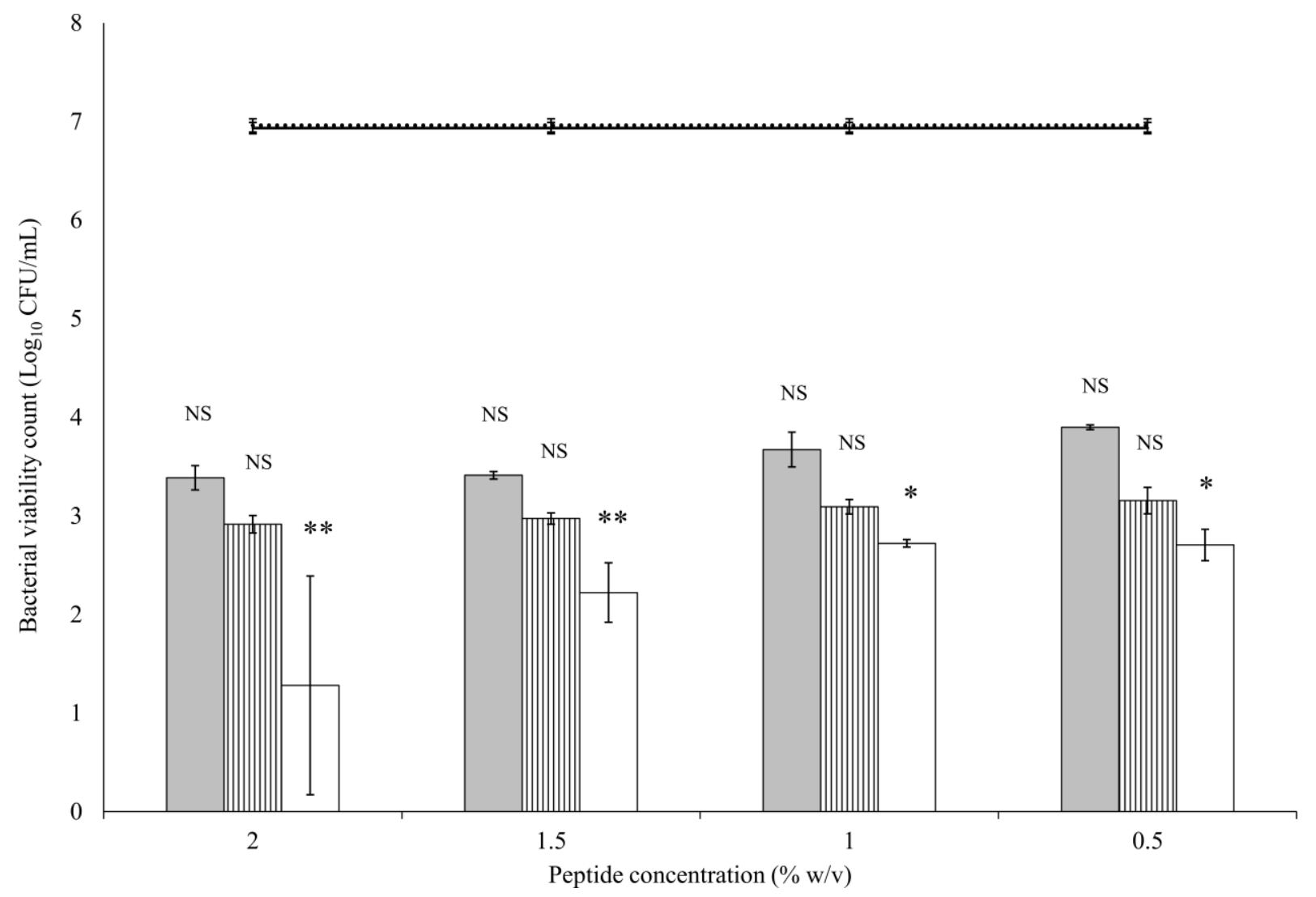

Figure 5. Logarithmic reduction in S. aureus (ATCC 6584) viable count $\left(\log _{10} \mathrm{CFU} / \mathrm{mL}\right.$ ) after 24 hour incubation with varying concentrations of NSAID-peptides. Results are displayed as a mean of six replicates. Key: grey column: IbuFFKK, striped column: IndFFKK, white column: NpxFFKK, dotted line: PBS control, black line: $2 \%$ w/v HPMC control. NS: no significant difference $(\mathrm{P} \geq 0.05),{ }^{*}: \mathrm{P}<0.05, * *: \mathrm{P}<0.01$ significant difference between $\log _{10} \mathrm{CFU} / \mathrm{mL}$ of NSAID-peptide and the negative control (PBS). 


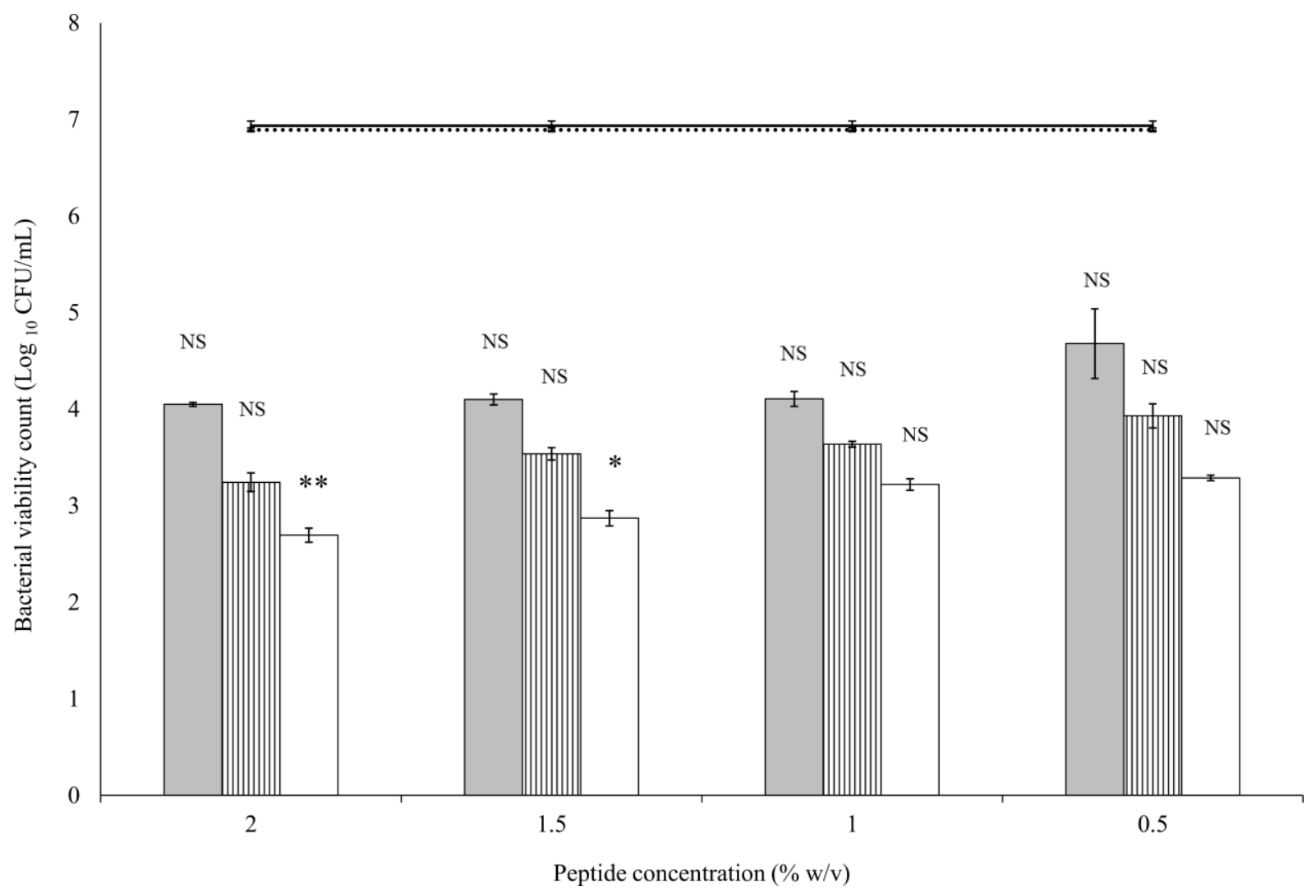

Figure 6. Logarithmic reduction in P. aeruginosa (PAO1) viable count $\left(\log _{10} \mathrm{CFU} / \mathrm{mL}\right)$ after 24 hour incubation with varying concentrations of NSAID-peptides. Results are displayed as a mean of six replicates. Key: grey column: IbuFFKK, striped column: IndFFKK, white column: NpxFFKK, dotted line: PBS control, black line: 2\% w/v HPMC control. NS: no significant difference $(\mathrm{P} \geq 0.05),{ }^{*}: \mathrm{P}<0.05,{ }^{* *}: \mathrm{P}<0.01$ significant difference between $\log _{10}$ CFU/mL of NSAID-peptide and the negative control (PBS). 


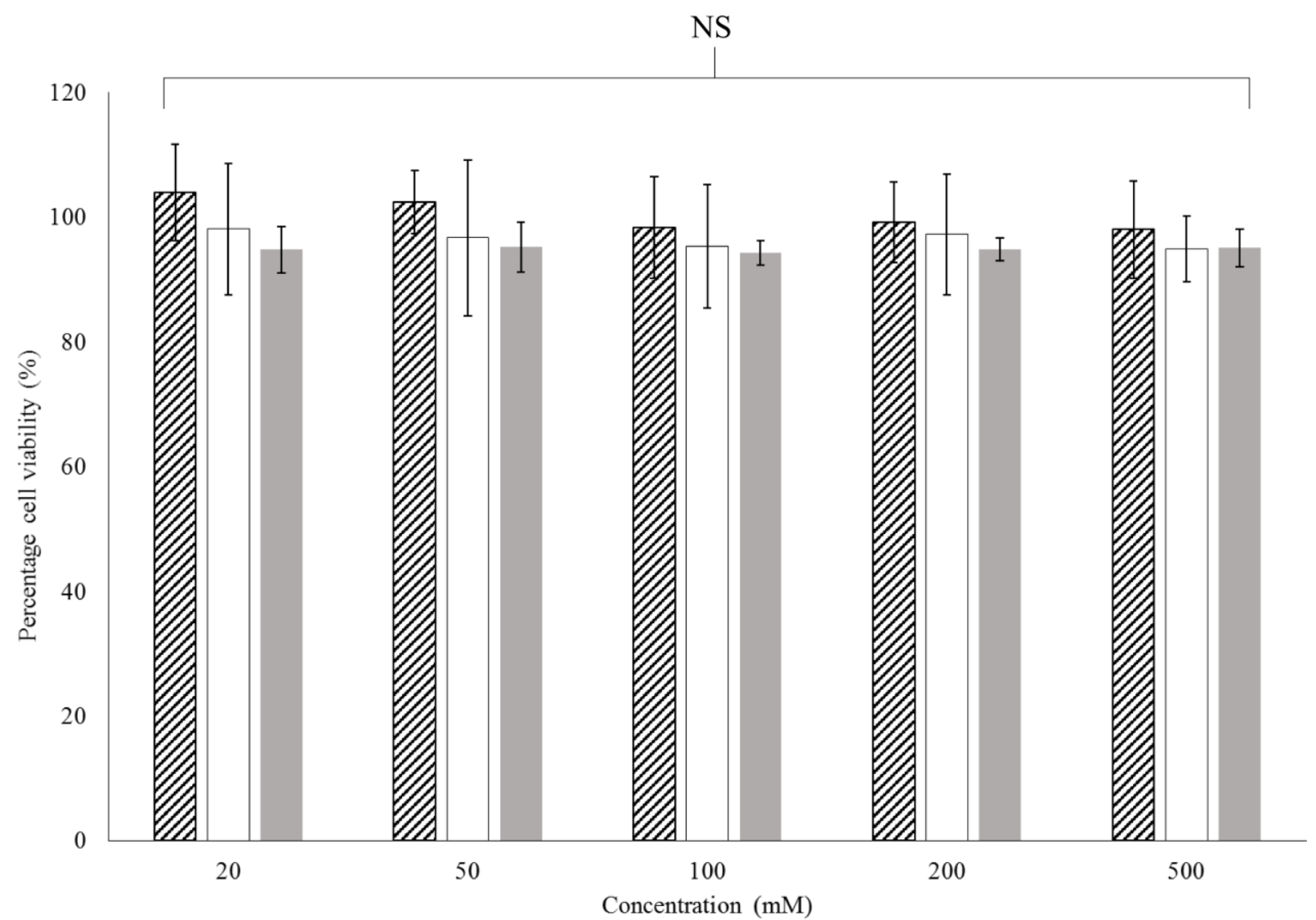

Figure 7. Percentage cell viability of NCTC clone 929 (ATCC CCL 1) cells after 24 hour exposure to varying concentrations of NSAID-peptides. Key: striped: IbuFFKK, white: IndFFKK, grey: NpxFFKK, ns: no significant difference $(\mathrm{P} \geq 0.05)$ between the NSAIDpeptide and the negative control (PBS). 
Table 1. Stepwise formulation of a self-assembling $\mathrm{pH}$-triggered 2\% w/v NSAID-peptide $(500 \mu \mathrm{L})$.

\begin{tabular}{lll}
\hline Formulation step & Constituent $^{\text {a) }}$ & Quantity \\
\hline 1 & NSAID-peptide & $10 \mathrm{mg}$ pre-weighed \\
2 & Deionized $\mathrm{H}_{2} \mathrm{O}$ or $\mathrm{D}_{2} \mathrm{O}$ & $200 \mu \mathrm{L}$ (in $50 \mu \mathrm{L}$ aliquots) \\
3 & $1 \mathrm{M} \mathrm{NaOH}$ or $\mathrm{NaOD}$ & $50 \mu \mathrm{L}$ (in $10 \mu \mathrm{L}$ aliquots) \\
4 & Deionized $\mathrm{H}_{2} \mathrm{O}$ or $\mathrm{D}_{2} \mathrm{O}$ & $200 \mu \mathrm{L}$ (in $50 \mu \mathrm{L}$ aliquots) \\
5 & $0.5 \mathrm{M} \mathrm{HCl}$ or $\mathrm{DCl}$ & $20 \mu \mathrm{L}$ (in $10 \mu \mathrm{L}$ aliquots) \\
6 & Deionized $\mathrm{H}_{2} \mathrm{O}$ or $\mathrm{D}_{2} \mathrm{O}$ & to $500 \mu \mathrm{L}$ \\
\hline
\end{tabular}

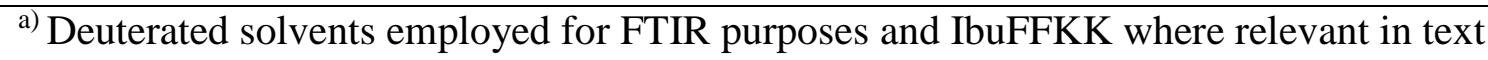

Table 2. Critical gelation concentrations (\% w/v) for each NSAID-peptide. Observation via inversion test.

NSAID-peptide Critical gelation concentration $(\% \mathrm{w} / \mathrm{v})$

\begin{tabular}{lc}
\hline IbuFFKK & $2^{\text {a) }}$ \\
IndFFKK & 1.5 \\
NpxFFKK & 0.4 \\
\hline
\end{tabular}

${ }^{\text {a) }}$ Deuterated solvents employed

Acknowledgements

This work was supported by the Queen's University Research Support Package for New Academic Staff for and a Royal Society Research Grant (RG150171) for GL. APM, SMG and SP acknowledge funding provided by a N. Ireland Department of Employment and Learning PhD studentship grant. The manuscript was written through contributions of all authors. All 
authors have given approval to the final version of the manuscript. APM, SG, ERD, JZ, SP, BFG and BX contributed equally. We acknowledge help from Prof. Dave Adams (University of Liverpool) for allowing us access to his Anton Paar Physica MCR301 rheometer for rheological studies.

\section{Supporting Information}

Self-assembling Ultrashort NSAID-Peptides: Multifunctional Antimicrobial and Antiinflammatory Nanomaterials

Alice P. McCloskey, Sophie M. Gilmore, Jie Zhou, Emily R. Draper, Brendan F. Gilmore, Bing Xu, Garry Laverty*

Ibuprofen-L-phenylalanine-L-phenylalanine-L-Lysine-L-Lysine-COOH (IbuFFKK). ${ }^{1} \mathrm{H}$ NMR (400 MHz, DMSO- $\left.d_{6}, \delta\right): 8.21-8.02(\mathrm{~m}, J=4.06,4 \mathrm{H} ; \mathrm{NH}), 7.66\left(\mathrm{~s}, J=4.13,4 \mathrm{H} ; \mathrm{NH}_{2}\right), 7.25-$ $6.99(\mathrm{~m}, J=14.26,14 \mathrm{H} ; \operatorname{Ar} \mathrm{H}), 4.57-4.18(\mathrm{~m}, J=4.40,4 \mathrm{H}, \mathrm{CHNH}), 3.03(\mathrm{q}, J=1.08,1 \mathrm{H}$; $\left.\mathrm{CHCH}_{3}\right), 2.84-2.68\left(\mathrm{~m}, J=10.75,8 \mathrm{H} ; \mathrm{CH}_{2} \mathrm{Ar}, 2 \mathrm{H} ; \mathrm{CH}_{2} \mathrm{NH}_{2}\right), 2.39\left(\mathrm{~d}, J=3.23,3 \mathrm{H} ; \mathrm{CH}_{3}\right)$, 1.54-1.07 (m, $\left.J=17.54,2 \mathrm{H} ; \mathrm{Ar} \mathrm{CH}_{2} \mathrm{CH}\left(\mathrm{CH}_{3}\right)_{2}, 1 \mathrm{H} ; \mathrm{CH}_{2} \mathrm{CH}\left(\mathrm{CH}_{3}\right)_{2}, 12 \mathrm{H} ; \mathrm{CH}_{2}\right), 0.86-0.83(\mathrm{~m}$, $\left.J=6.51,6 \mathrm{H} ; \mathrm{CH}_{3}\right)$. EIMS $m / z(\%): 756.46(100)\left[\mathrm{M}^{+}\right], 757.46(46.5)\left[\mathrm{M}^{+}+\mathrm{H}\right]^{+}, 758.46(10.6)$ $\left[\mathrm{M}^{+}+2 \mathrm{H}\right]^{+} ;(\mathrm{ESI}) m / z:[\mathrm{M}+\mathrm{H}]^{+}$calcd for $\mathrm{C}_{43} \mathrm{H}_{60} \mathrm{~N}_{6} \mathrm{O}_{6}, 756.99$; found, 756.46 . 


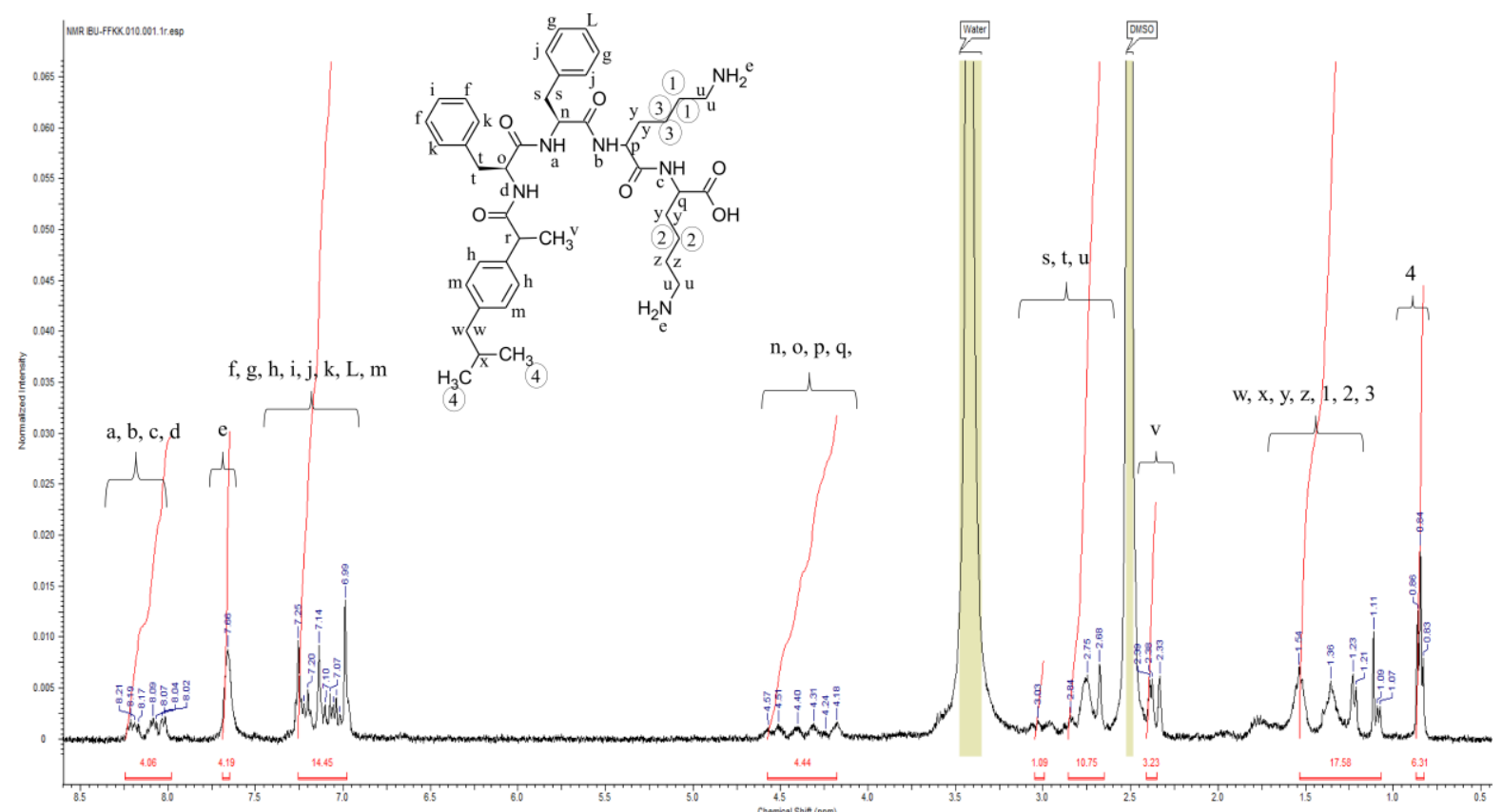

Figure S1. ${ }^{1} \mathrm{H}$ NMR.spectra for IbuFFKK $\left(\mathrm{C}_{2} \mathrm{D}_{6} \mathrm{OS}\right.$, TMS standard, $\left.400 \mathrm{MHZ}\right)$.

Indomethacin-L-phenylalanine-L-phenylalanine-L-Lysine-L-Lysine-COOH (IndFFKK).

${ }^{1} \mathrm{H}$ NMR (400 MHz, DMSO- $d_{6}, \delta$ ): 8.21-8.16 (m, $\left.J=2.59,1 \mathrm{H} ; \mathrm{NH}, 1 \mathrm{H} ; \mathrm{Ar} \mathrm{H}\right), 7.63-7.55$ (m, $J=4.16,1 \mathrm{H} ; \mathrm{Ar} \mathrm{H}, 2 \mathrm{H} ; \mathrm{NH}), 7.22-6.62\left(\mathrm{~m}, J=17.33,14 \mathrm{H} ; \mathrm{Ar} \mathrm{H}, 1 \mathrm{H} ; \mathrm{NH}, 4 \mathrm{H} ; \mathrm{NH}_{2}\right), 4.56-$ $4.16(\mathrm{~m}, J=5.49,4 \mathrm{H} ; \mathrm{CHNH}), 3.74-3.67\left(\mathrm{~m}, J=4.41,3 \mathrm{H} ; \mathrm{CH}_{3}, 2 \mathrm{H} ; \mathrm{CH}_{2} \mathrm{CO}\right), 3.03-2.68(\mathrm{~m}$, $\left.J=14.50,4 \mathrm{H} ; \mathrm{CH}_{2} \mathrm{NH}_{2}, 4 \mathrm{H} ; \mathrm{CH}_{2} \mathrm{Ar}\right), 2.33\left(\mathrm{~s}, J=3.02,3 \mathrm{H} ; \mathrm{CH}_{3}\right), 1.89-1.24(\mathrm{~m}, J=21.08$, 12H; $\left.\mathrm{CH}_{2}\right)$. EIMS m/z (\%): $893.39(100)\left[\mathrm{M}^{+}\right], 894.39$ (51.9) $\left[\mathrm{M}^{+}-\mathrm{H}\right], 895.38(32)\left[\mathrm{M}^{+}-\right.$ 2H], 896.39 (16.6); (ESI) $m / z:[\mathrm{M}+\mathrm{H}]^{+}$calcd for $\mathrm{C}_{49} \mathrm{H}_{58} \mathrm{ClN}_{7} \mathrm{O}_{8}, 894.47$; found, 893.39. 


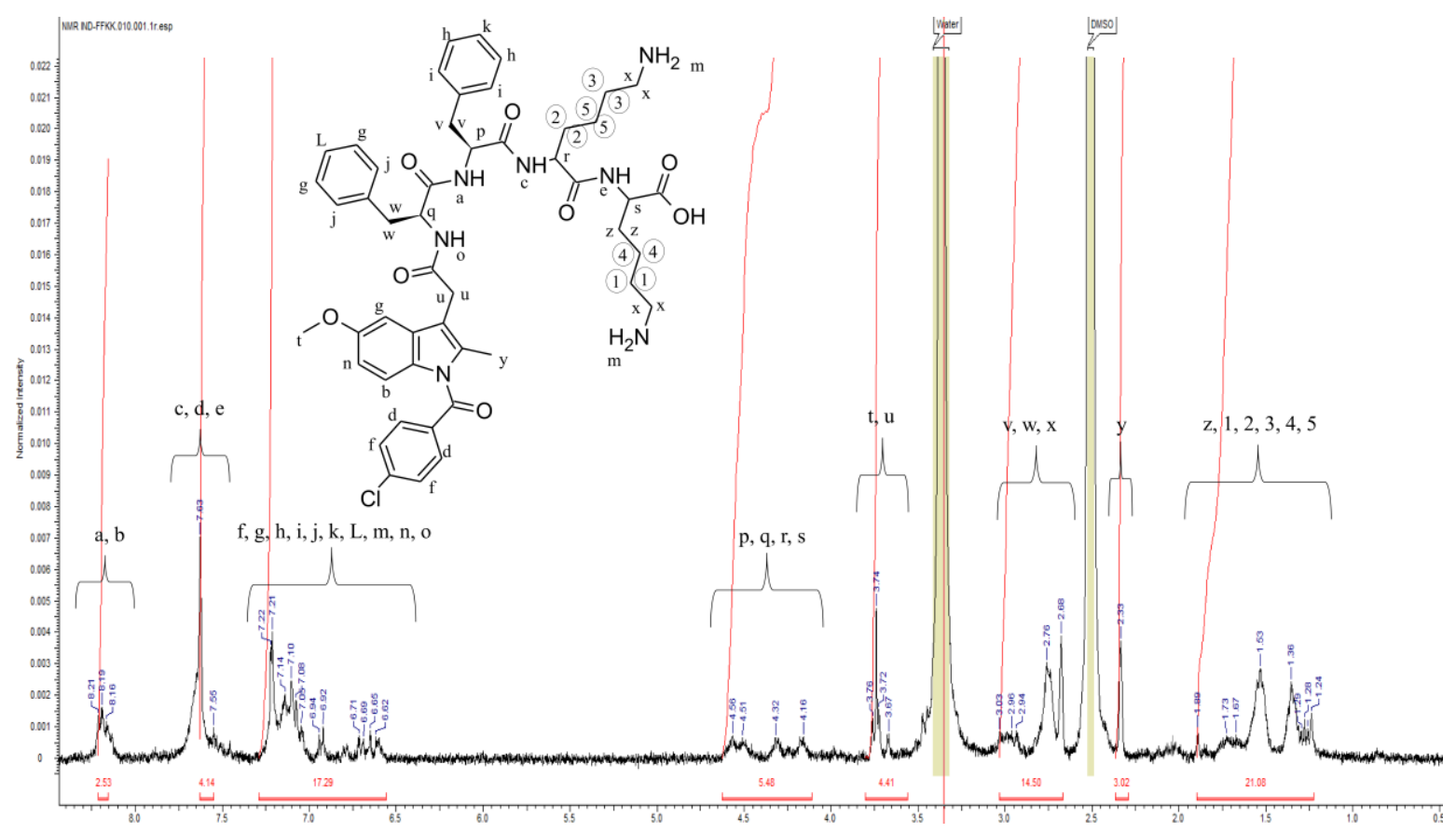

Figure S2. ${ }^{1} \mathrm{H}$ NMR.spectra for IndFFKK $\left(\mathrm{C}_{2} \mathrm{D}_{6} \mathrm{OS}\right.$, TMS standard, 400MHZ).

Naproxen-L-phenylalanine-L-phenylalanine-L-Lysine-L-Lysine-COOH (NpxFFKK).

${ }^{1} \mathrm{H}$ NMR (400 MHz, DMSO- $d_{6}, \delta$ ): 8.22-8.04 (m, $J=5.53,3 \mathrm{H} ; \mathrm{NH}, 2 \mathrm{H}$; Ar H), 7.75-7.05 (m, $\left.J=21.43,14 \mathrm{H} ; \mathrm{Ar} \mathrm{H}, 4 \mathrm{H} ; \mathrm{NH}_{2}\right), 4.50-3.71\left(\mathrm{~m}, J=6.20,4 \mathrm{H} ; \mathrm{CHNH}, 1 \mathrm{H} ; \mathrm{Ar} \mathrm{CHCH}_{3}\right), 2.98-$ $2.68\left(\mathrm{~m}, J=9.974 \mathrm{H} ; \mathrm{Ar} \mathrm{CH}_{2}, 4 \mathrm{H} ; \mathrm{CH}_{2} \mathrm{NH}_{2}\right), 2.33\left(\mathrm{~s}, J=3.10,3 \mathrm{H} ; \mathrm{CH}_{3}\right), 1.73-1.03(\mathrm{~m}, J=$ 21.71, 12H; $\left.\mathrm{CH}_{2}, 3 \mathrm{H} ; \mathrm{CH}_{3}\right) . \operatorname{EIMS~m/z~(\% ):~} 780.42(100)\left[\mathrm{M}^{+}\right], 781.42(47.6)\left[\mathrm{M}^{+}-\mathrm{H}\right]$, $782.43(11.1)\left[\mathrm{M}^{+}-2 \mathrm{H}\right]$; (ESI) $m / z:[\mathrm{M}+\mathrm{H}]^{+}$calcd for $\mathrm{C}_{44} \mathrm{H}_{56} \mathrm{~N}_{6} \mathrm{O}_{7}, 780.97$; found, 780.42. 


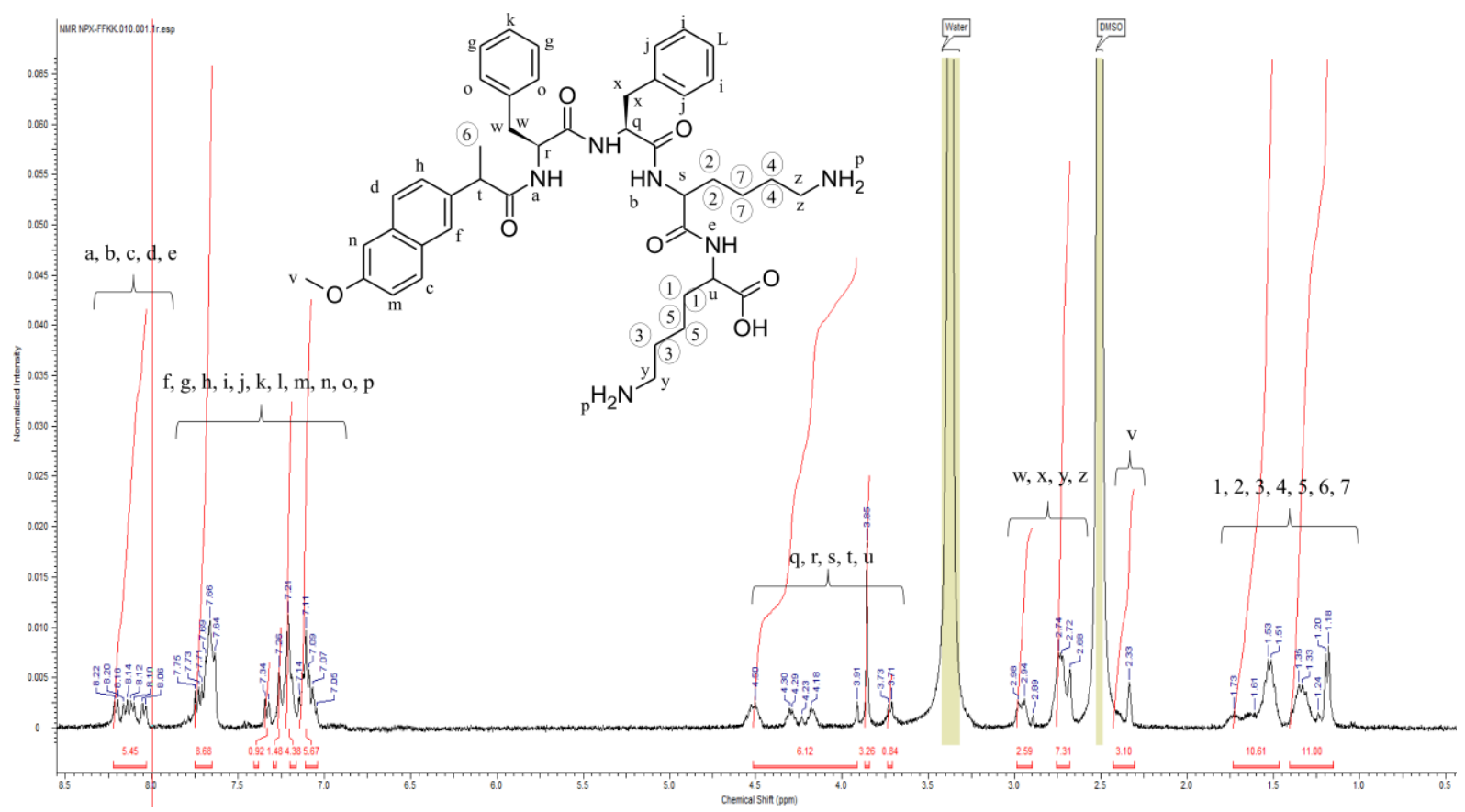

Figure S3. ${ }^{1} \mathrm{H}$ NMR.spectra for NpxFFKK $\left(\mathrm{C}_{2} \mathrm{D}_{6} \mathrm{OS}\right.$, TMS standard, 400MHZ).

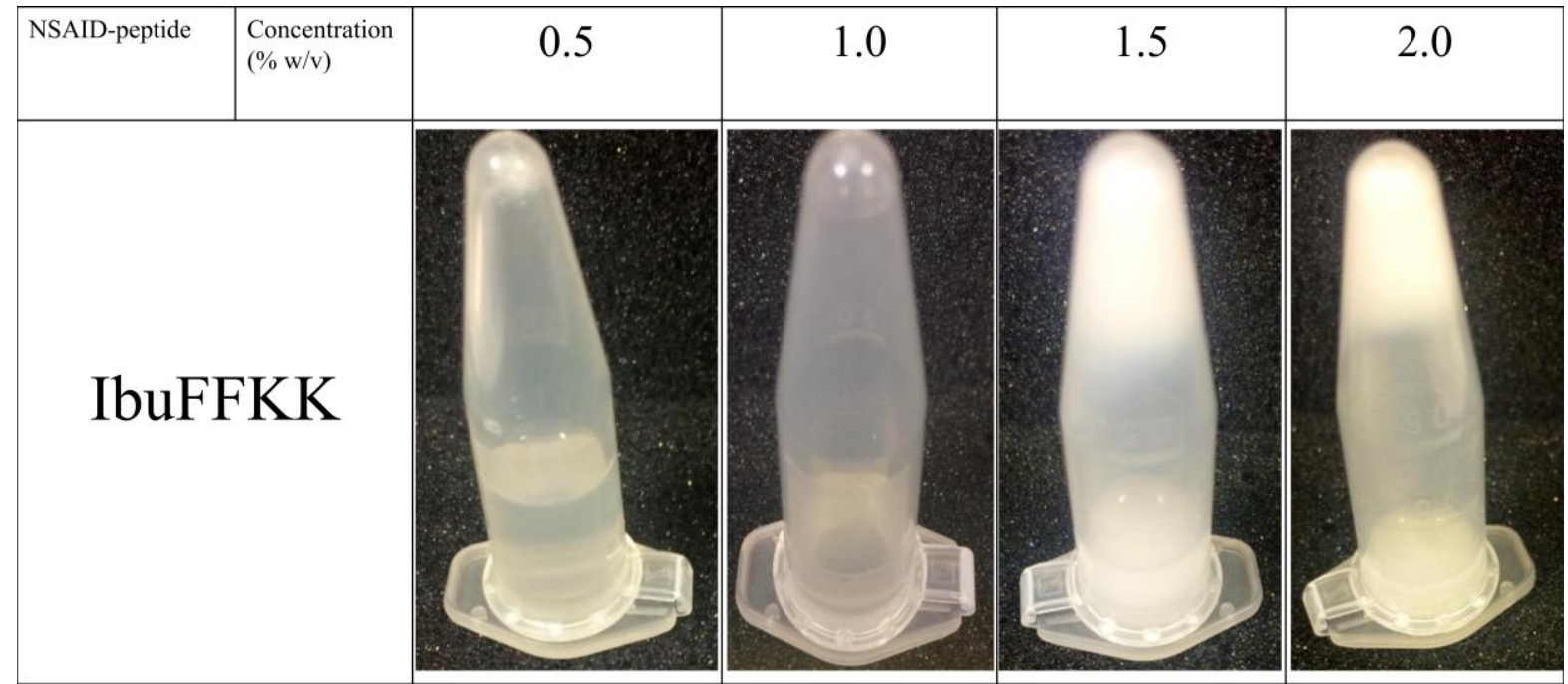

Figure S4. Gel inversion assay for IbuFFKK pH 7.4, $\mathrm{H}_{2} \mathrm{O}$ primary vehicle. 


\begin{tabular}{|l|l|l|l|l|}
\hline $\begin{array}{l}\text { NSAID- } \\
\text { peptide }\end{array}$ & $\begin{array}{l}\text { Concentration } \\
\% \mathrm{w} / \mathrm{v})\end{array}$ & 0.5 & 1.0 & 1.5 \\
\hline & & & & \\
\hline & & & \\
\hline
\end{tabular}

Figure S5. Gel inversion assay for IbuFFKK pH 7.4, $\mathrm{D}_{2} \mathrm{O}$ primary vehicle.

\begin{tabular}{|l|l|l|l|l|}
\hline $\begin{array}{l}\text { NSAID- } \\
\text { peptide }\end{array}$ & $\begin{array}{l}\text { Concentration } \\
\text { \% w/v })\end{array}$ & 0.5 & 1.0 & 1.5 \\
\hline & & & & \\
IndFFKK & & & & \\
\hline
\end{tabular}

Figure S6. Gel inversion assay for IndFFKK pH 7.4, $\mathrm{H}_{2} \mathrm{O}$ primary vehicle. 


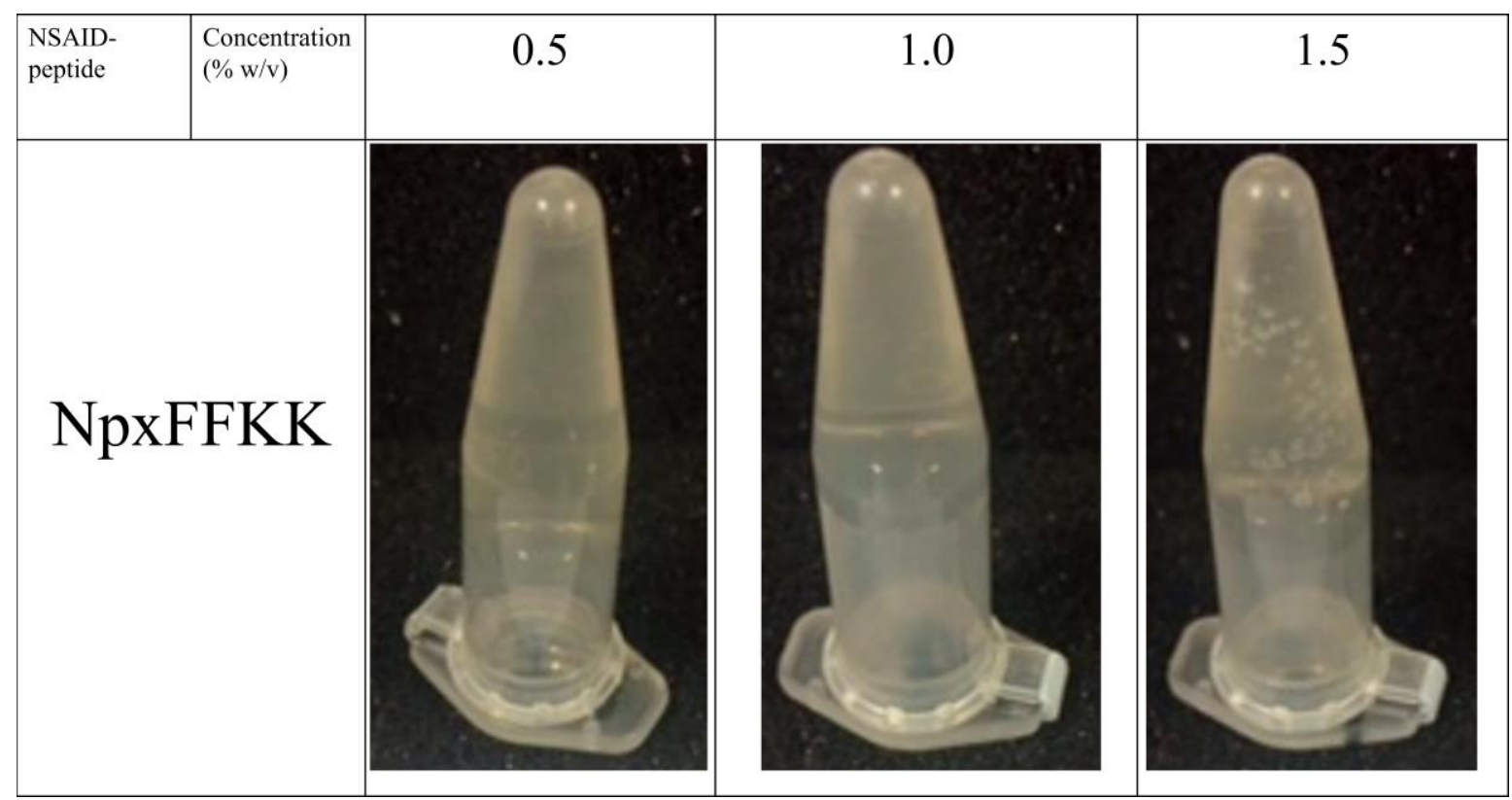

Figure S7. Gel inversion assay for NpxFFKK pH 7.4, $\mathrm{H}_{2} \mathrm{O}$ primary vehicle.

a)

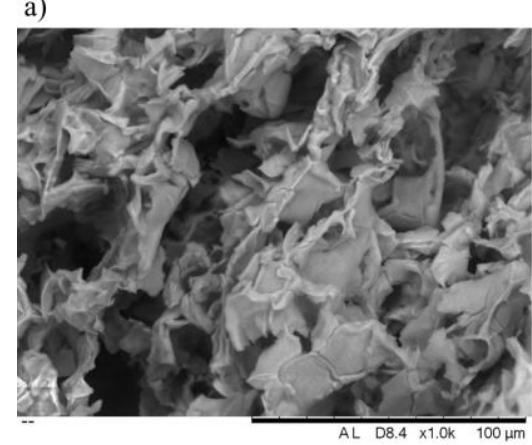

b)

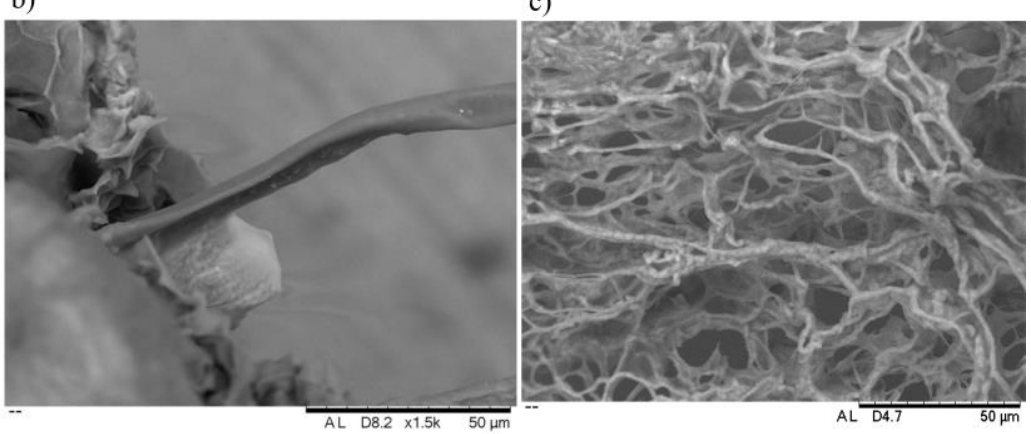

Figure S8. Cryo-SEM images of $2 \%$ w/v (a) IbuFFKK $\left(\mathrm{D}_{2} \mathrm{O}\right)$, (b) IndFFKK $\left(\mathrm{H}_{2} \mathrm{O}\right)$, (c) NpxFFKK $\left(\mathrm{H}_{2} \mathrm{O}\right)$. 
a)

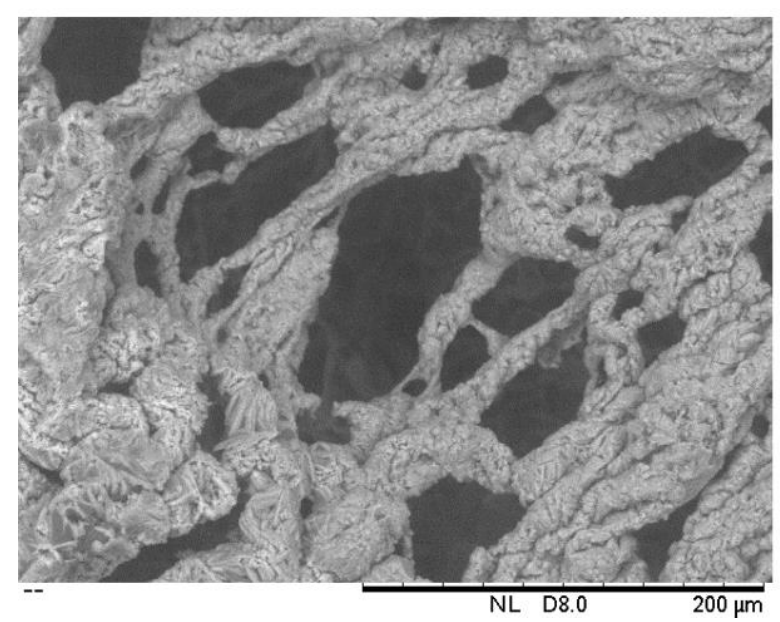

b)

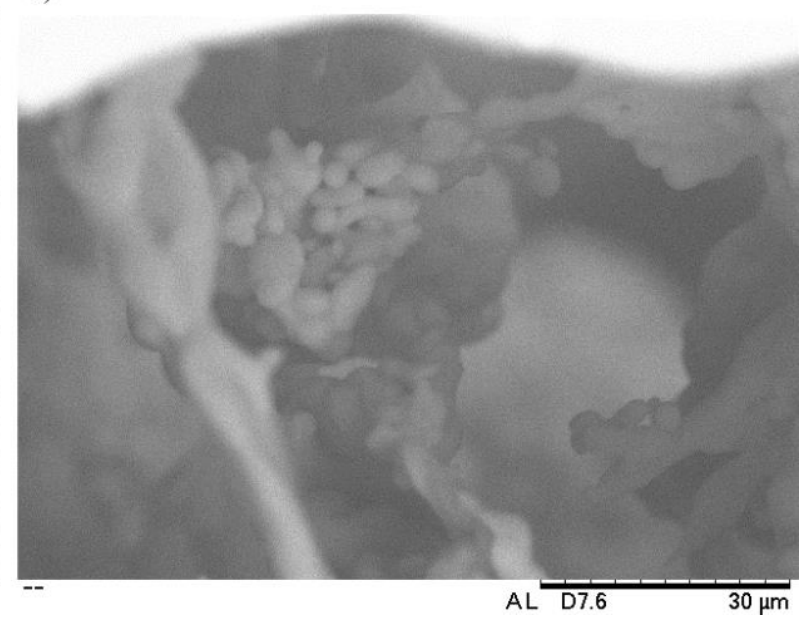

Figure S9. Cryo-SEM images of $2 \%$ w/v IbuFFKK $\left(\mathrm{H}_{2} \mathrm{O}\right.$ primary vehicle).
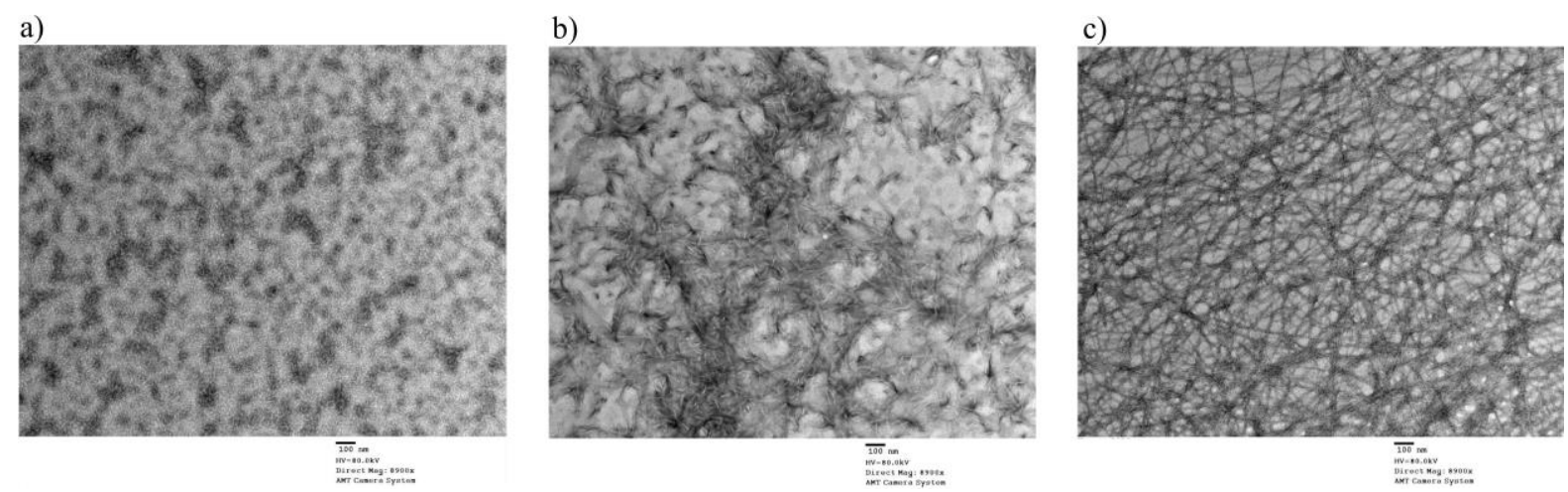

Figure S10. TEM images of 2\% w/v (8900x) (a) IbuFFKK $\left(\mathrm{D}_{2} \mathrm{O}\right)$, (b) $\operatorname{IndFFKK}\left(\mathrm{H}_{2} \mathrm{O}\right)$, (c)NpxFFKK $\left(\mathrm{H}_{2} \mathrm{O}\right)$. 


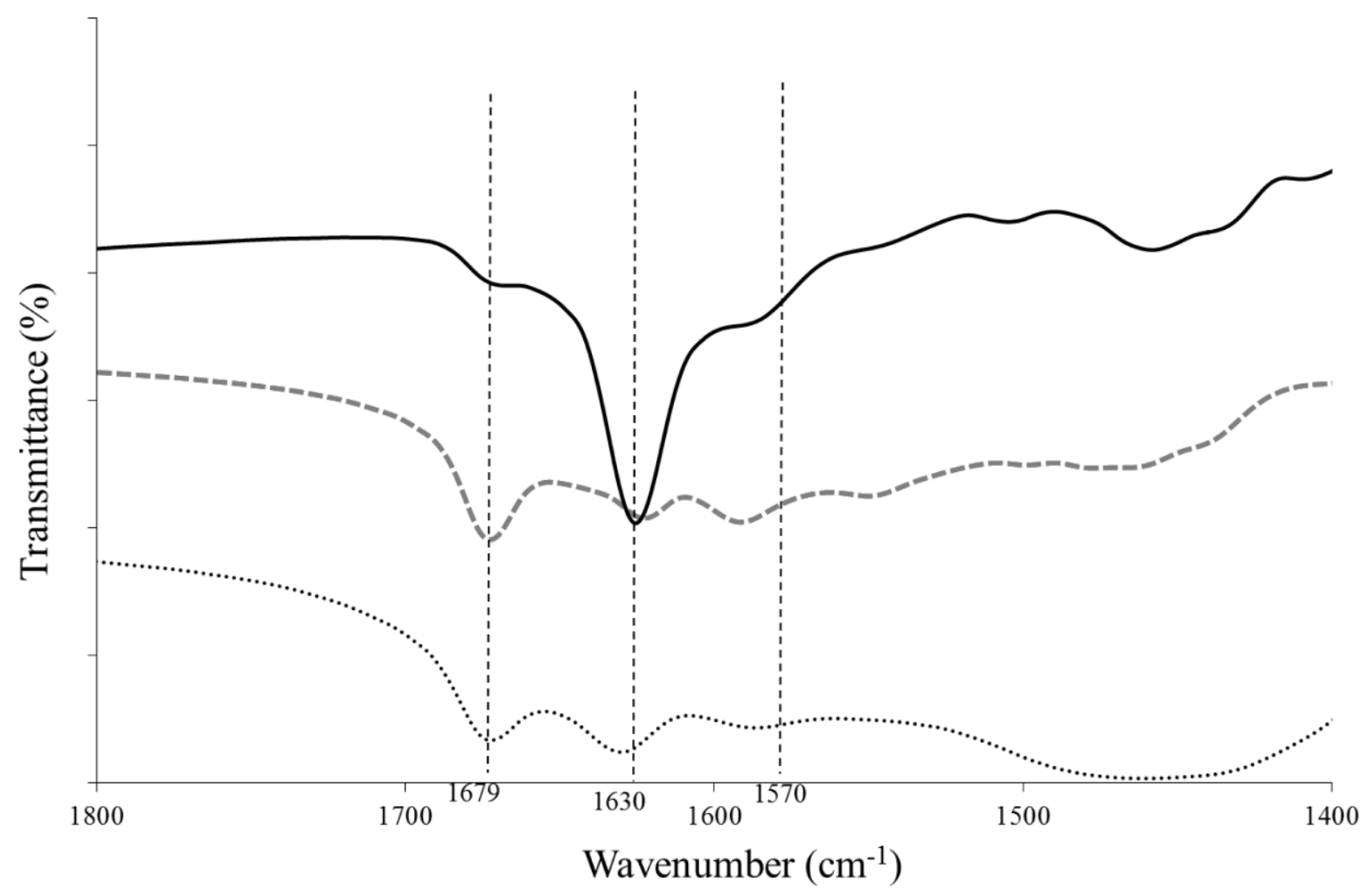

Figure S11. FTIR spectra displaying amide band of $2 \%$ w/v NSAID-peptides in deuterated solvents. Key: dotted line: IbuFFKK, dashed line: IndFFKK , full line: NpxFFKK.

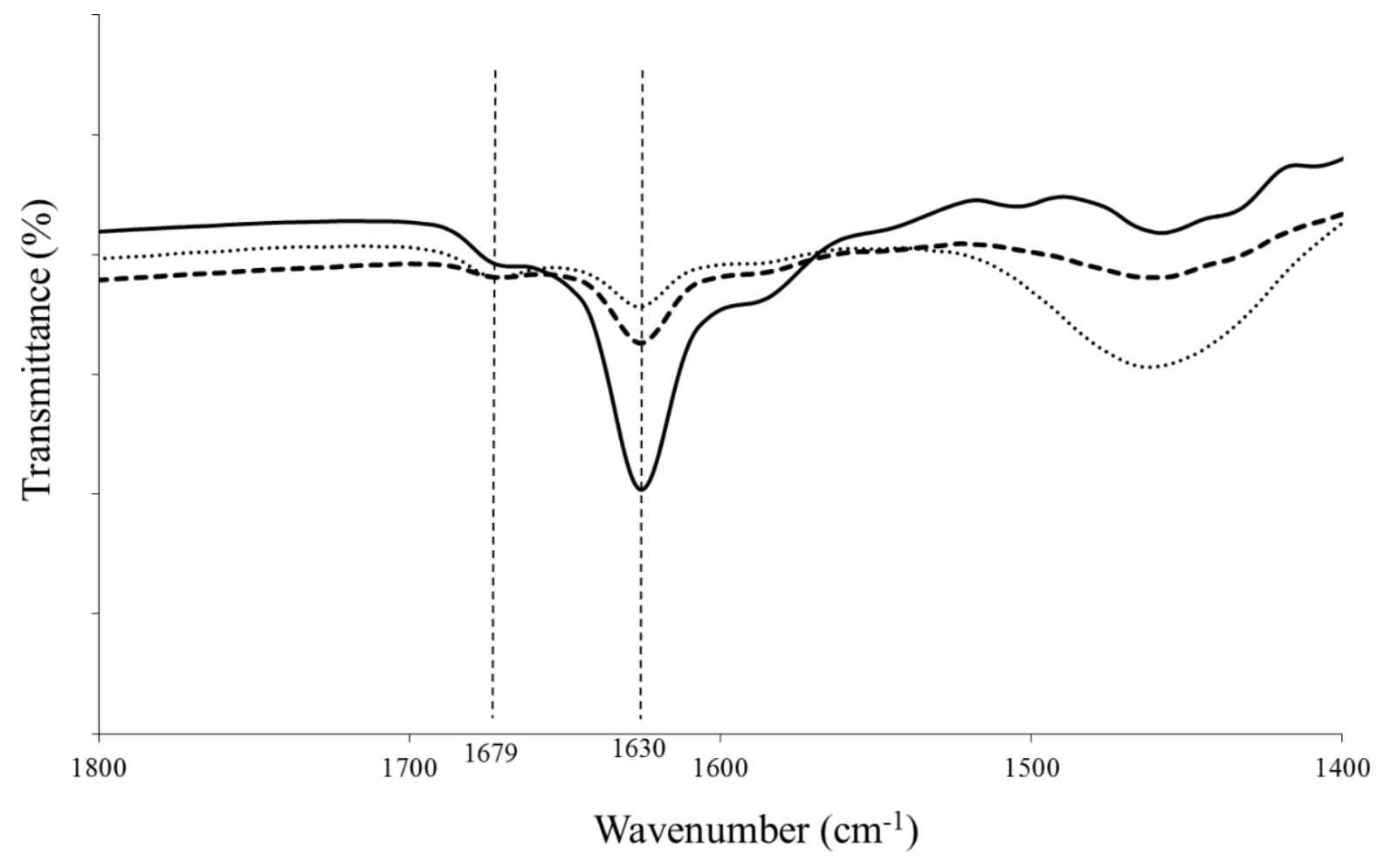


Figure S12. FTIR spectra displaying amide band of 0.5-2\% w/v NpxFFKK peptide. Key: dotted line: $0.5 \% \mathrm{w} / \mathrm{v}$, dashed line: $1.5 \% \mathrm{w} / \mathrm{v}$, full line: $2 \% \mathrm{w} / \mathrm{v}$.

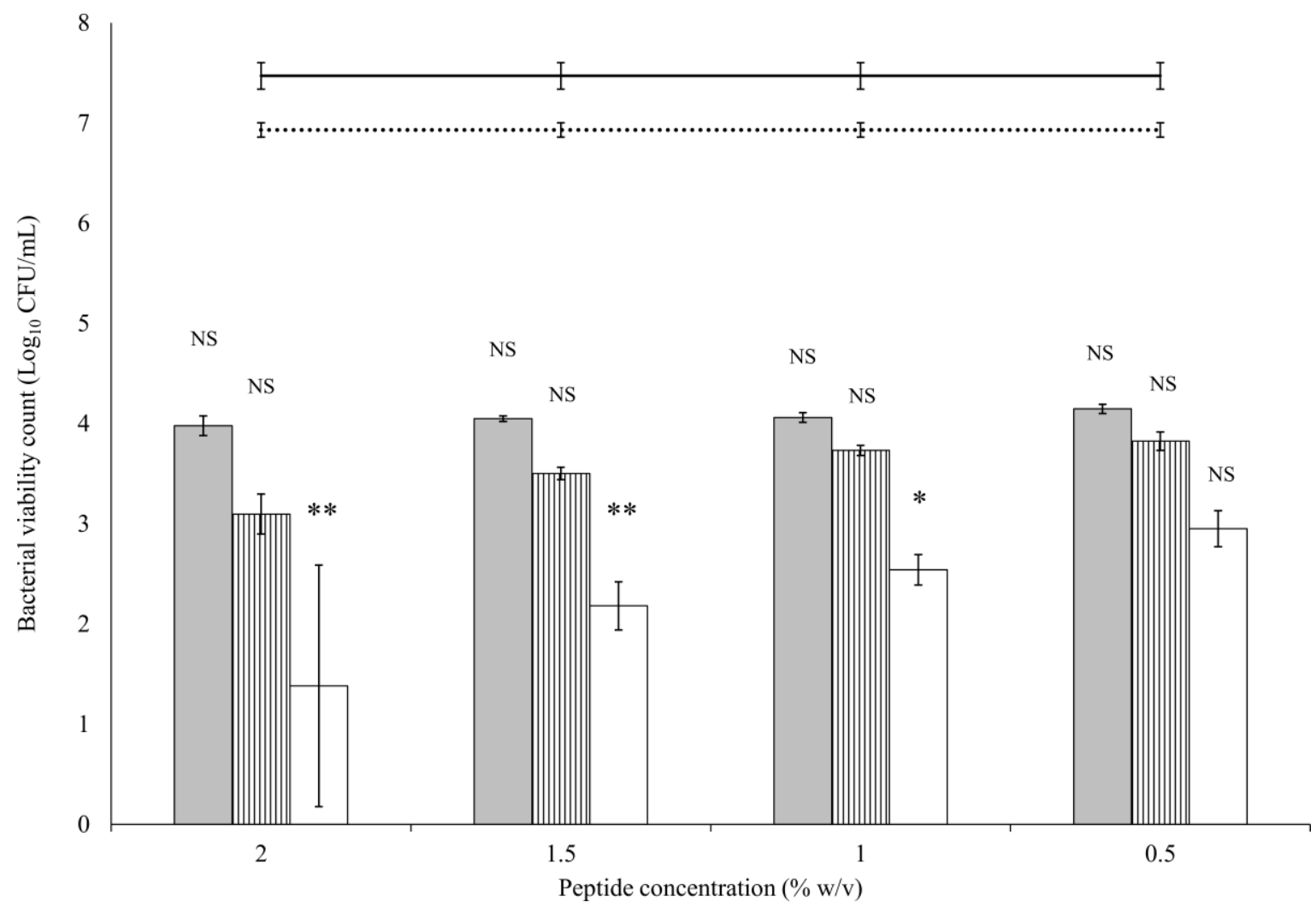

Figure S13. Logarithmic reduction in S. epidermidis (ATCC 35984) viable count ( $\log _{10}$ $\mathrm{CFU} / \mathrm{mL}$ ) after 24 hour incubation with varying concentrations of NSAID-peptides. Results are displayed as a mean of six replicates. Key: grey column: IbuFFKK, striped column: IndFFKK, white column: NpxFFKK, dotted line: PBS control, black line: $2 \%$ w/v HPMC control. NS: no significant difference $(\mathrm{P} \geq 0.05), *: \mathrm{P}<0.05, * *: \mathrm{P}<0.01$ significant difference between $\log _{10} \mathrm{CFU} / \mathrm{mL}$ of NSAID-peptide and the negative control (PBS). 


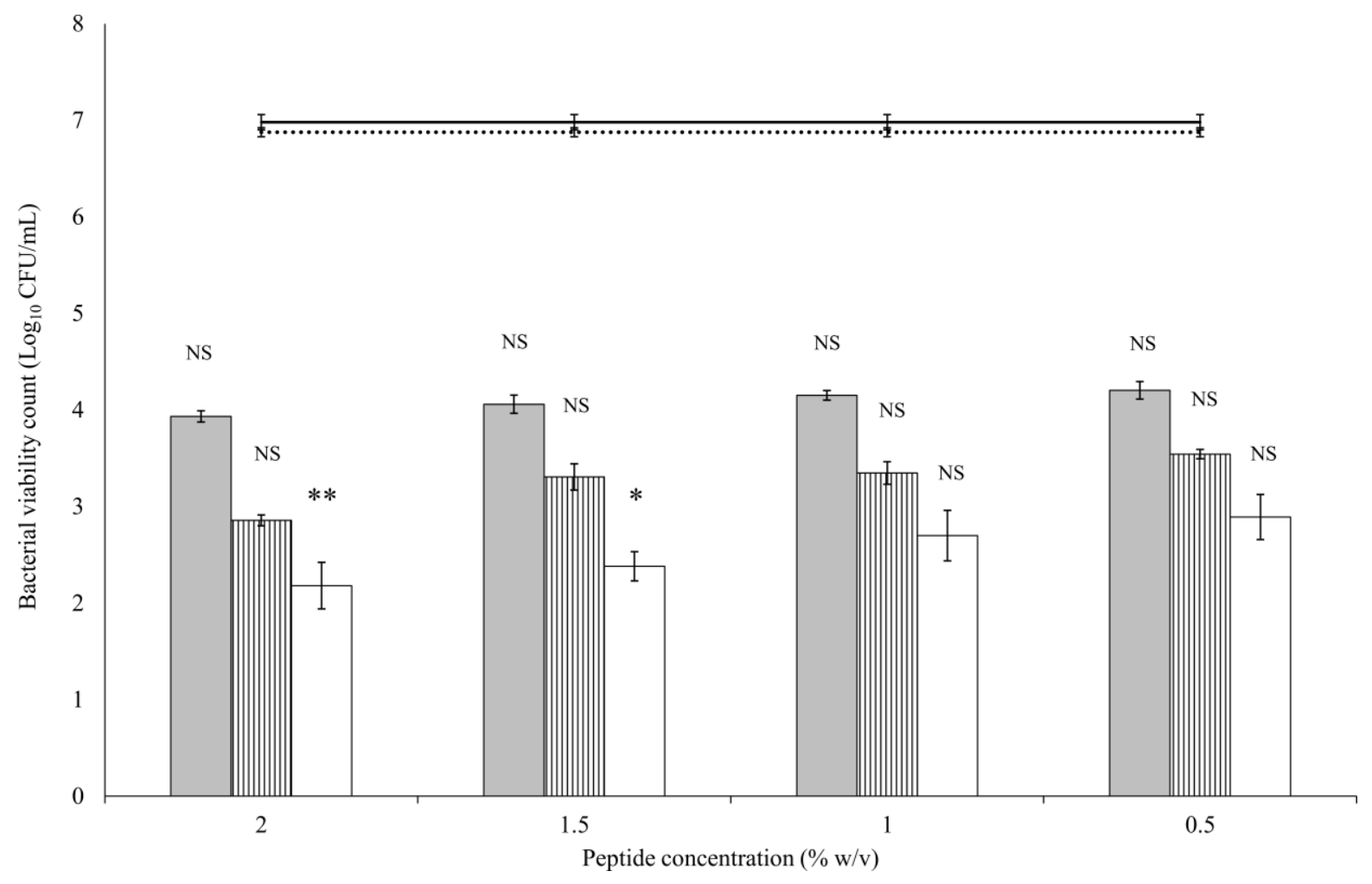

Figure S14. Logarithmic reduction in E. coli (ATCC 11303) viable count ( $\left.\log _{10} \mathrm{CFU} / \mathrm{mL}\right)$ after 24 hour incubation with varying concentrations of NSAID-peptides. Results are displayed as a mean of six replicates. Key: grey column: IbuFFKK, striped column: IndFFKK, white column: NpxFFKK, dotted line: PBS control, black line: $2 \%$ w/v HPMC control. NS: no significant difference $(\mathrm{P} \geq 0.05),{ }^{*}: \mathrm{P}<0.05,{ }^{*}: \mathrm{P}<0.01$ significant difference between $\log _{10}$ $\mathrm{CFU} / \mathrm{mL}$ of NSAID-peptide and the negative control (PBS).

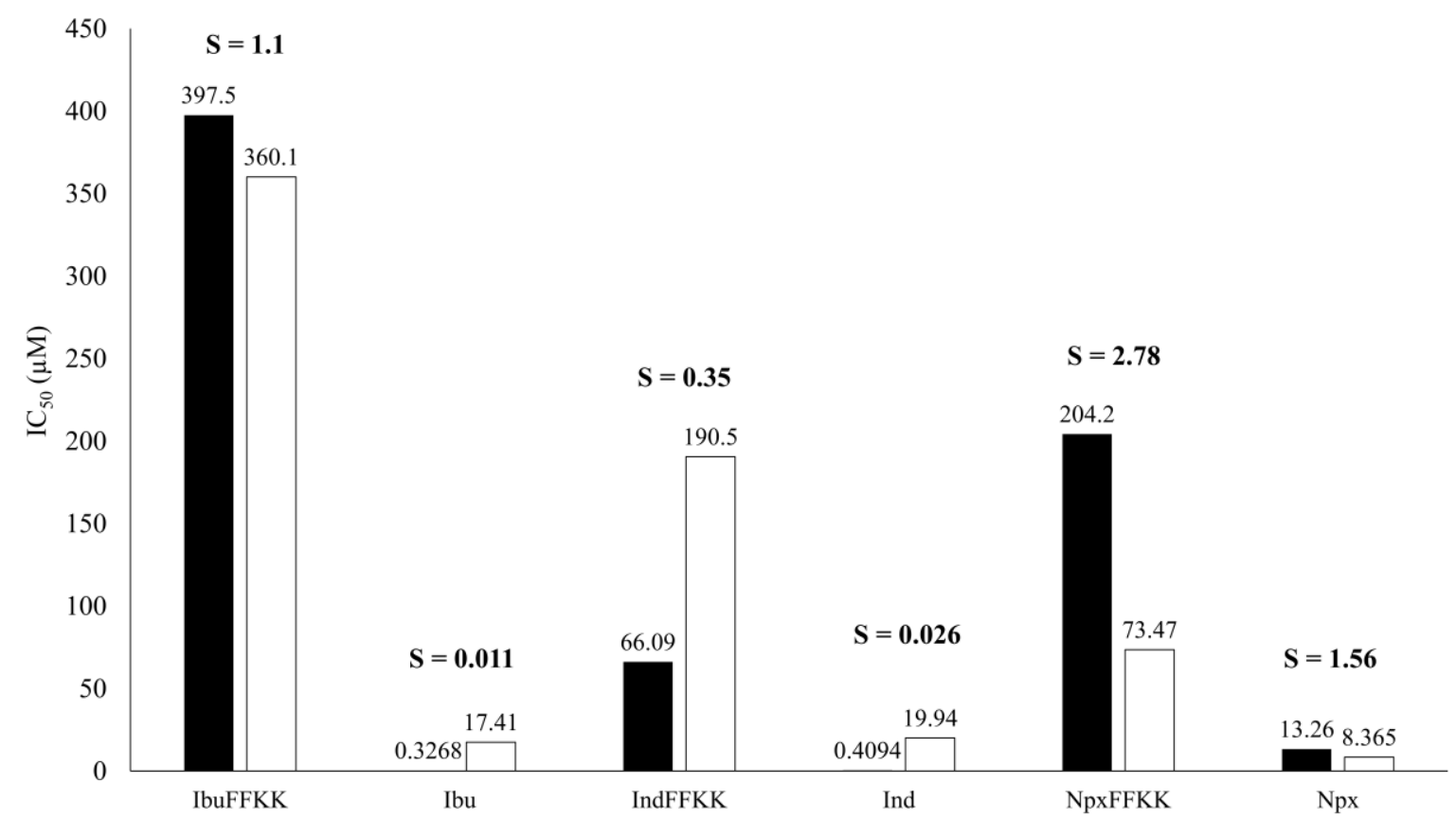


Figure S15. IC 50 values of NSAID-peptide and NSAIDs only molecules corresponding to inhibition of COX-1 (black column) and COX-2 (white column) enzymes. Selectivity (S) is defined as the ratio of the $\mathrm{IC}_{50}$ values relative to COX-1: COX-2.

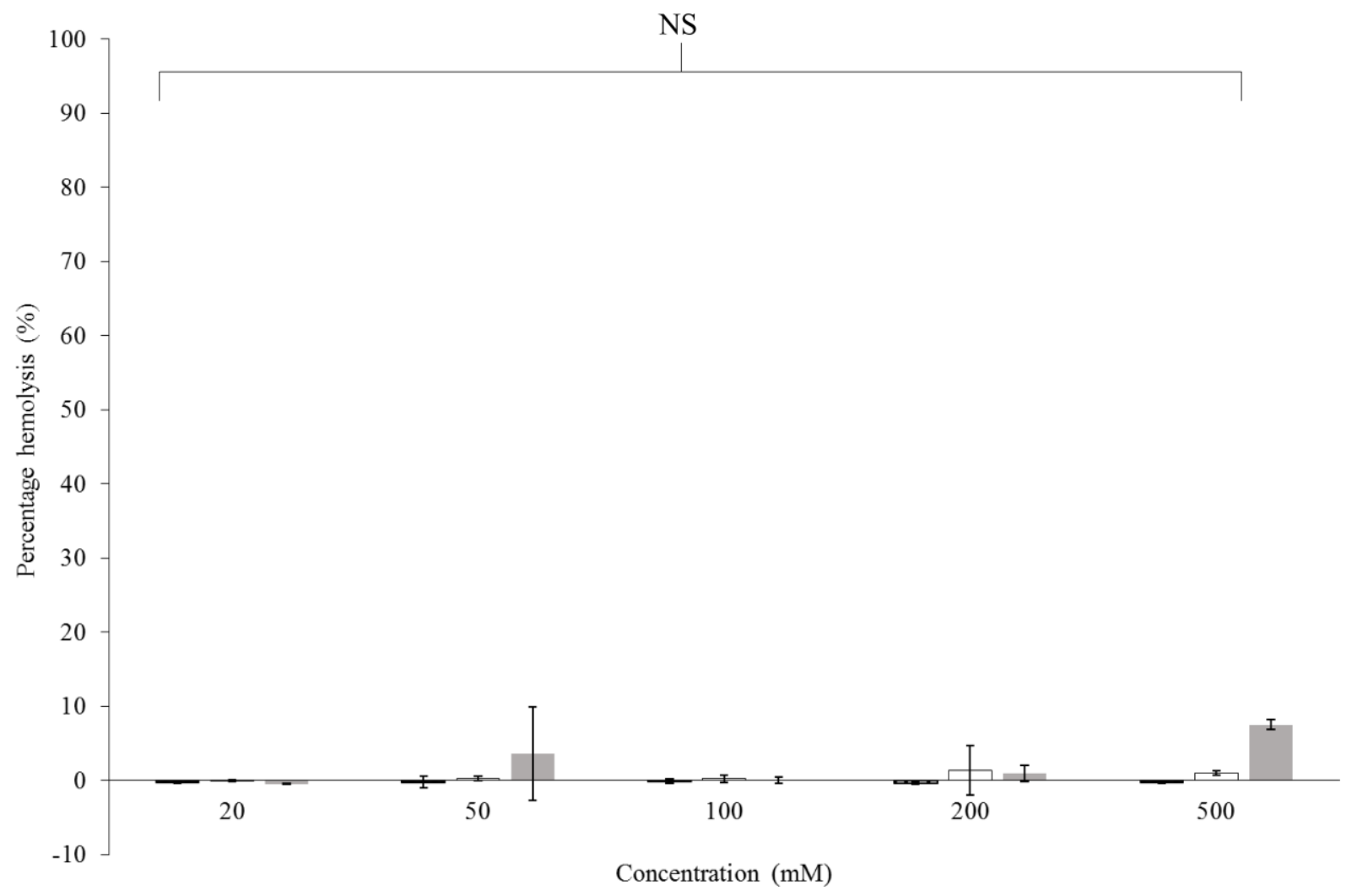

Figure S16. Percentage hemolysis of equine erythrocytes after 1 hour exposure to varying concentrations of NSAID-peptides. Key: striped: IbuFFKK, white: IndFFKK, grey: NpxFFKK, NS: no significant difference ( $\mathrm{P} \geq 0.05)$ between the NSAID-peptide and the negative control (PBS). 